\title{
Review
}

\section{Understanding the Outcomes Measures used in Huntington Disease Pharmacological Trials: A Systematic Review}

\author{
Noelle E. Carlozzi ${ }^{\mathrm{a}, *}$, Angela Miciura ${ }^{\mathrm{a}}$, Nicholas Migliore ${ }^{\mathrm{a}}$ and Praveen Dayalu ${ }^{\mathrm{b}}$ \\ ${ }^{a}$ Department of Physical Medicine and Rehabilitation, University of Michigan, Ann Arbor, MI, USA \\ ${ }^{\mathrm{b}}$ Department of Neurology, University of Michigan, Ann Arbor, MI, USA
}

\begin{abstract}
Background: The identification of the gene mutation causing Huntington disease has raised hopes for new treatments to ease symptoms and slow functional decline. As such, there has been a push towards designing efficient pharmacological trials (i.e., drug trials), especially with regard to selecting outcomes measures that are both brief and sensitive to changes across the course of the disease, from subtle prodromal changes, to more severe end-stage changes.

Objectives: Recently, to aid in efficient development of new HD research studies, the National Institute of Neurological Disorders and Stroke (NINDS) published recommendations for measurement selection in HD. While these recommendations are helpful, many of the recommended measures have little published data in HD. As such, we conducted a systematic review of the literature to identify the most common outcomes measures used in HD clinical trials.

Methods: Major medical databases, including PubMed, Embase, CINAHL, and the Cochrane Central Register of Controlled Trials, were used to identify peer-reviewed journal articles in English from 2001 through April 2013; 151 pharmacological trials were identified.

Results: The majority of HD clinical trials employed clinician-reported outcomes measures (93\%); patient reported outcome measures (11\%) and observer reported outcome measures (3\%) were used with much less frequency.

Conclusions: We provide a review of the most commonly used measures across these trials, compare these measures to the clinical recommendations made by the NINDS working groups, and provide recommendations for selecting measures for future clinical trials that meet the Food and Drug Administration standards.
\end{abstract}

Keywords: Huntington disease, clinical trials, outcomes measures

Huntington disease (HD) is an autosomal dominant neurodegenerative disease affecting approximately 3 per 100,000 people worldwide [1]. Individuals with the abnormal CAG expansion in the HTT gene experience a multitude of behavioral, cognitive and motor symptoms over the course of the disease. Such symp-

\footnotetext{
${ }^{*}$ Correspondence to: Noelle E. Carlozzi, PhD, Department of Physical Medicine and Rehabilitation, North Campus Research Complex, Building 14, 2800 Plymouth Road, Ann Arbor, MI 481092800, USA. Tel.: +1 734763 8917; Fax: +1 734763 7186; E-mail: carlozzi@med.umich.edu.
}

toms include depression, anxiety, personality change, irritability, dementia, chorea, imbalance, clumsiness, falls, and swallowing difficulty [2]. Symptoms often begin insidiously around age 40, and progress steadily over 15-20 years, leading to death [3].

The identification of the gene mutation causing HD, as well as continued advances in understanding the pathogenesis of the disease, has raised hopes for evaluating new clinical compounds designed to alleviate symptoms and to slow functional decline, if not to cure the disease outright. However, most outcomes 
measures currently used in HD pharmacological trials are narrow in focus and do not adequately capture changes in function at the most meaningful level, for patients [4-6]. Without sensitive and valid outcomes measures, it is impossible to evaluate the effectiveness of potential treatment interventions.

In addition, the evaluation of new clinical compounds is complicated by other factors. HD is considered a rare or orphan disease, making very large clinical trials impractical. Furthermore, it is currently impossible to ascertain, for at-risk individuals nearing the typical age of onset, when the disease might "manifest" itself [7]. Thus, if a 38-year old is given a compound and does not exhibit symptoms for several more years, there is no way to know whether the compound prevented or delayed clinical onset for that individual. Given such complexities, well-designed pharmacological trials are paramount in ultimately deciding whether a new treatment is effective in HD. One of the best ways to make these clinical trials more efficient and robust is to maximize the sensitivity of our clinical assessment tools.

The HD community has long recognized the need for more sensitive, HD-specific measurement. Most recently, the National Institute for Neurological Disorder and Stroke (NINDS) has established a group of HD clinicians and researchers to make recommendations for common data elements (CDE) in HD clinical trials and research. The NINDS CDE groups included working groups in: Motor, Imaging and Biomarkers, Biochemical Markers, Genetics, Epidemiology/Environment, Function Outcomes/PROs, Behavior/Psychiatry, Pathology, Operations, Cognition, and Scale Metrics and Statistics [8]. Each group was to review the state of the science to determine which clinical measures are the most useful/sensitive in an HD population. To this end, they have published a list of recommendations for measurement selection in clinical research in HD (see Table 1 for a summary of recommended measures) [8]. The utility of each measure was classified as follows: core (recommended for use in all HD studies), supplemental (recommended for targeted use in HD studies), or exploratory (not enough data to make a full recommendation, but some evidence to suggest utility in HD). While these recommendations provide an excellent starting point for measurement selection for clinical studies, each working group developed their own criteria for determining classifications in a manner not consistent across working groups. For example, some groups decided to recommend measures based on expert opinion, some based on literature review (of varying levels of rigor).
The need for sensitive assessments in HD research is particularly acute in pharmacological trials (i.e., drug trials). Specifically, in determining the efficacy of a drug, the Food and Drug Administration (FDA) requires evidence to support dosing selection, safety, tolerability, and the ability of the new drug to improve some specific facet(s) of the disease in question (and when applicable, compared to other existing treatments) [9]. Clinical trials might use a variety of primary and secondary outcomes measures which can include clinical outcomes assessments (COAs), biomarkers and animal models. Specifically, COAs can fall into one of three categories: patient-reported outcome (PRO) assessment, observer reported outcome assessment (ObsRO), or clinical-reported outcome (ClinRO) assessment. PROs are self-report measures (i.e., responses come directly from the patient without any interpretation by a clinician/observer) that are focused on evaluating health [10]. ObsRO are measures that are made by an individual that knows the patient, but does not necessarily have professional training (e.g., family member, friend), and ClinRO are assessments that are made by physicians using clinical judgment and/or interpretation. While a PRO can evaluate all aspects of health (direct assessment of symptoms, observable and unobservable behaviors), ObsRO and ClinRO assessments can only be used to evaluate observable behaviors (which does not include the direct assessment of symptoms or unobservable behaviors and feelings). Qualifying assessments must be standardized (administration and responses), have acceptable psychometric properties including validation data in the targeted patient population.

Given the relative importance of maximizing HD pharmacological trials, the recognition in the field that sensitive HD-specific measures are lacking, and the fact that hundreds of trials have already been conducted in HD, the purpose of this paper was to systematically review the literature to report the most commonly used measures in previous HD clinical trials. We provide a summary of the most frequently used measures identified by the systematic review, compare and contrast these measures with those recommended by the NINDS CDE working groups, and provide recommendations for future measurement selection based on this information.

\section{METHODS}

We completed a comprehensive search of major medical databases including PubMed, Embase, Cumu- 
Table 1

Specific outcomes measures recommended by the NINDS HD CDE working groups

Outcomes measure NINDS classification

CLINICIAN REPORTED OUTCOMES (ClinRO)

Motor Functioning

NIH Toolbox-Motor Function:Endurance (2-min. walk test),

Locomotion (4-meter walk test) [56]

Timed Up and Go [57]

UHDRS Motor Exam [18]

10-Meter Walking Test [58]

Cognitive Functioning

Circle Tracing [59]

Cued Movement Sequencing [60]

Emotional Recognition [61]

Hopkins Verbal Learning Test- Revised (HVLT-R) [62]

Map Search Task [63]

Mental Rotation [64]

Montreal Cognitive Assessment (MoCA) [65]

Phonemic Verbal Fluency (PVF) [60]

Self-Paced Tapping [66]

Simple and Two-Choice Reaction Time [60]

Speeded Tapping Test [60]

Spot the Change [31]

Stroop Color Naming [23]

Stroop Word Reading [23]

Stroop Interference [23]

Symbol Digit Modalities Test [24]

Trailmaking Test [67]

Verbal Fluency [22]

Supplemental

Emotional/Behavioral Functioning

Apathy Evaluation Scale [68]

Apathy Scale [69]

Columbia Suicide Severity Scale [70]

Concise Health Risk Tracking Scale [71]

Hospital Anxiety and Depression Scale [44]

Irritability Scale [12]

Problem Behaviors Assessment-Short [35]

Functional Limitations

Physical Performance Test (PPT) [72]

UHDRS Functional Assessment Checklist [9]

UHDRS Independence Scale [9]

UHDRS Total Functional Capacity [9]

Other Assessments

OSU TBI Form [73]

The Retrospective Lifestyle Questionnaire [74]

Exploratory

Exploratory

Core

Exploratory

Supplemental

Supplemental

Supplemental

Supplemental

Exploratory

Exploratory

Exploratory

Supplemental Core

Supplemental Core

Supplemental

Core

Core

Supplemental

Core

Supplemental

Supplemental

Supplemental

Supplemental

Supplemental

Supplemental

Supplemental Core

Exploratory

Core (for dx only)

Core (for dx only)

Core (for dx only)

Supplemental

Supplemental

PATIENT REPORTED OUTCOMES (PROs)

Cognitive Functioning

Florida Obsessive Compulsive Inventory [75]

Lifetime Cognitive Activity [76]

Padua-Inventory-OCD-Wash-U-Revised [77]

Emotional/Behavioral Functioning

Concise Health Risk Tracking Scale [71]

Functional Limitations

FURST/CHDI [78]

HD Work Function Scale [79]

Quality of Life

EuroQol 5-D (EQ-5D) [80]

Huntington's Disease health-related Quality

of Life questionnaire (HDQoL) [50]

NeuroQOL [48]

PROMIS [46]

SF-36 [81]
Supplemental

Supplemental

Supplemental

Supplemental

Exploratory

Exploratory

Exploratory

Supplemental

Exploratory

Exploratory

Exploratory 
Table 1

(Continued)

\begin{tabular}{|c|c|}
\hline Outcomes measure & NINDS classification \\
\hline Sickness Impact Profile (SIP) [81] & Exploratory \\
\hline World Health Organization Disability Assessment Schedule (WHODAS) [82] & Exploratory \\
\hline World Health Organization Disability Assessment Schedule 2.0 (WHODAS 2.0) [83] & Exploratory \\
\hline \multicolumn{2}{|l|}{ Other Assessments } \\
\hline Cambridge Brain Repair Centre (BRC) HD Sleep Questionnaire [84] & Supplemental \\
\hline Food Frequency Questionnaire [85] & Supplemental \\
\hline Godin Leisure-Time Exercise Questionnaire [86] & Supplemental \\
\hline \multicolumn{2}{|l|}{ NIH Diet History Questionnaire (DHQ) [87] } \\
\hline & Supplemental \\
\hline Nurse's Health Study Questionnaire(NHQ) [88] & Supplemental \\
\hline PD DOC Mini Environmental Risk Questionnaire & Supplemental \\
\hline Pittsburgh Sleep Quality Index [89] & Supplemental \\
\hline Scale for Outcomes of Parkinson's disease-Sleep [90] & Supplemental \\
\hline
\end{tabular}

lative Index to Nursing and Allied Health, and the Cochrane Central Register of Controlled Trials for articles highlighting HD clinical trials. Key search terms were broad and included Huntington, Huntington's chorea, Huntington's disease, Huntingtons disease, Huntington disease: limits (controlled clinical trial OR randomized clinical trial, human). This search yielded a total of 1060 publications. Publications were then subject to the following inclusion criteria:

1. Study must be reported in English or Spanish;

2. Publication must highlight the evaluation of a pharmacological/drug trial (we chose to focus our systematic review on pharmacological treatments in HD due to: a. fact that the FDA requires the use of standardized assessments with acceptable psychometric properties; b. the clinical importance of identifying cure; and c. the potential for clinical compounds to yield large effect sizes);

3. HD must be included as a part of the clinical population examined;

4. Publication must be published between 2001 and be in press prior to April 2013; and

5. Publication must not be a duplicate.

For each study that was extracted for inclusion, demographic data were recorded, including age of the study population and disease duration, if given. The outcomes utilized in each study were also recorded, as well as the study design, drug being examined and primary findings (Supplementary Table 1).

We utilize the systematic review to identify the most frequently utilized outcomes measures in HD clinical research. For the most frequently used measures, we also reviewed available psychometric data in HD and/or other clinical populations. This data, in conjunction with the recommendations made by the NINDS, was used to make recommendations for measurement selection for future HD clinical trials. Psychometric data in HD (especially evidence of responsiveness to change in HD), was weighted more heavily than data in other clinical populations for making recommendations. Furthermore, in cases where multiple measures might have good evidence for inclusion, we often selected the measure with the most evidence to support its utility in HD.

\section{RESULTS}

The combined searches yielded 1060 abstracts. We eliminated 245 duplicate records, 18 non-English or Spanish records, 206 review articles, 48 that did not include original data, 36 non-HD articles, 21 animal studies, 12 others, and 323 studies that were either non-pharmacological interventions or observational studies; a total of 151 articles were retained for this review (see Fig. 1).

Table 2 provides a breakdown of the different types of primary, secondary and exploratory outcomes measures used in the HD pharmacological studies using FDA COA categories; specifically, most studies used clinician rated measures (i.e., 93\%), whereas only a small number of clinical trials used PROs $(11 \%)$ or ObsRO's (3\%). Table 3 highlights the specific outcome measures, by COA category, used in HD clinical trials. ClinRO measures included assessments of motor function, functional limitation, emotional/behavioral function, and cognitive function. The most frequently used ClinRO motor measures included the Unified Huntington's Disease Rating Scale (UHDRS) motor exam, Abnormal Involuntary Movements Scale (AIMS), Marsden \& Quinn Chorea Severity Scale, and the Quantitative Neurological Examination (QNE), whereas the most frequently used ClinRO functional limitation measures included the Total Functional 


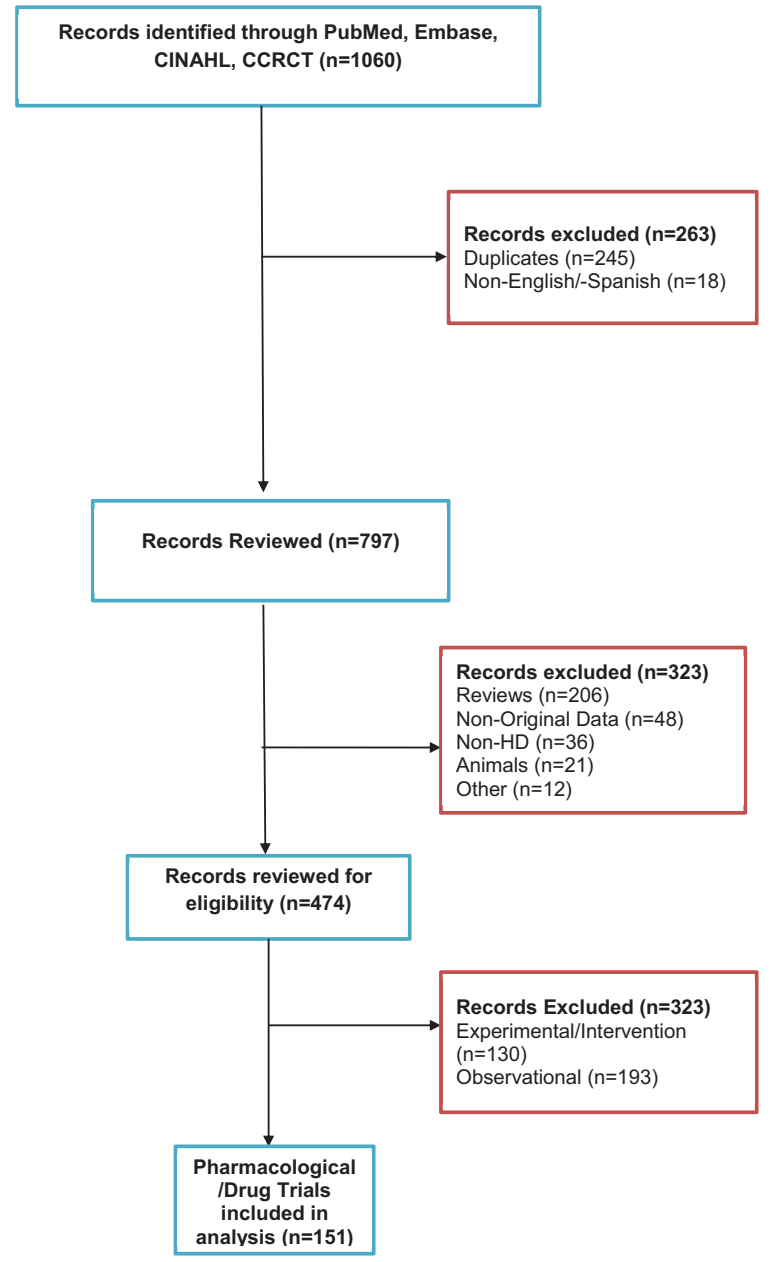

Fig. 1. Flow diagram of the studies included in this systematic review.

Capacity Scale, the Functional Assessment Scale and the Independence Scale from the UHDRS. In addition, the most frequently used emotional/behavioral measures were the UHDRS Behavioral Exam and the Hamilton Rating Scale for Depression (HAM-D), and the most frequently used ClinRo measures of cognition were from the UHDRS (Verbal Fluency, Symbol Digit Modalities Test and the Stroop). The Clinical Global Impression Scale was also used with some frequency as a ClinRO measure. PROs and ObsRO were used infrequently.

Of the measures that were identified in the systematic review, only 9 were included in the recommendations from the NINDS (see Table 4). Eight of these were ClinRO measures: a motor functioning measure (the UHDRS Motor Exam), several cognitive measures (Verbal Fluency, Stroop, SDMT, and Trailmaking), and several Functional Assessment mea-
Table 2

Breakdown of type of clinical outcome measures used in HD pharmacological trials

\begin{tabular}{lc}
\hline $\begin{array}{l}\text { Types of clinical } \\
\text { outcome assessments }\end{array}$ & $\begin{array}{c}\text { Number of } \\
\text { articles (out of 151) }\end{array}$ \\
\hline Patient Reported Outcomes (PRO) & $17(11 \%)$ \\
Observer Reported Outcomes (ObsRO) & $4(3 \%)$ \\
Clinical Reported Outcomes (ClinRO) & $140(93 \%)$ \\
Other (biomarkers, MRI, physiology) & $46(30 \%)$ \\
\hline
\end{tabular}

sures (UHDRS TFC, UHDRS Functional Assessment Scale and UHDRS Independence Scale). Our recommendations for measurement selection for future pharmacological trials are also included in Table 4.

\section{DISCUSSION}

Results from the systematic review indicated that most HD pharmacological trials use ClinRO measures as their primary endpoints. Furthermore, there is a surprising lack of PROs and ObsRO measures in these studies. In addition, there is only limited overlap between the measures that have been recommended by the NINDS, and the measures that have hitherto been used in HD clinical trials. Below, we discuss the strengths and weaknesses of the measures that have thus far been used in HD clinical trials, compare these measures to the NINDS CDE recommendations, discuss our recommendations for future measurement selection, and highlight areas where additional work is needed.

\section{ClinRO measurements (used in $93 \%$ of HD clinical trials)}

The majority of the outcomes measures used in HD pharmacological trials are clinician-rated (93\% of clinical trials in HD employed ClinRO measures). This is not particularly surprising given the paucity of HD-specific PRO and ObsRO measures, as well as the concerns about the reliability of self-report data, especially in individuals with later stage HD [11-17]. ClinRO measures include assessments of motor functioning, cognitive functioning, functional limitations, and emotional/behavioral functioning.

\section{ClinRO motor functioning measures}

Among the more commonly used motor functioning measures are the UHDRS Motor Exam [18], Abnormal Involuntary Movements Scale (AIMS) [19], Marsden and Quinn Chorea Severity Score [20], and Quantitative Neurological Exam (QNE) [21] (see Table 3). The 
Table 3

Specific outcomes measures being used in HD pharmacological trials

\begin{tabular}{|c|c|}
\hline Outcomes measure & Number of studies using measure $(\mathrm{s})$ \\
\hline \multicolumn{2}{|l|}{ CLINICIAN REPORTED OUTCOMES (ClinRO) } \\
\hline \multicolumn{2}{|l|}{ Motor Functioning } \\
\hline UHDRS Motor Exam [18] & $61^{*}$ \\
\hline Abnormal Involuntary Movement Scale (AIMS) [19] & 17 \\
\hline Marsden \& Quinn Chorea Severity Scale [20] & 6 \\
\hline Quantitative Neurologic Examination [32] & 3 \\
\hline HD Motor Rating Scale [91]; Rockland-Simpson Dyskinesia Rating Scale [92] & 1 \\
\hline \multicolumn{2}{|l|}{ Cognitive Functioning } \\
\hline \multicolumn{2}{|l|}{ UHDRS Cognitive Exam [18] } \\
\hline Verbal Fluency [22] & 46 \\
\hline Stroop [23] & 43 \\
\hline Symbol Digit Modalities Test [24] & 38 \\
\hline Mini-Mental State Exam [93] & 21 \\
\hline Trailmaking Test [67] & 9 \\
\hline WAIS Digit Span $[94,95]$ & 5 \\
\hline Benton Visual Retention Test [96]; Buschke Selective Reminding Test [97] & 4 \\
\hline $\begin{array}{l}\text { AD Assessment Scale-cognitive [98]; Raven’s Progressive Matrices Test [99]; WAIS Digit } \\
\text { Symbol }[94,95]\end{array}$ & 3 \\
\hline $\begin{array}{l}\text { Hopkins Verbal Learning Test [100]; Wechsler Memory Scales [101, 102]; WAIS Block Design } \\
\text { [94, 95]; WAIS Arithmetic [94, 95]; WAIS FSIQ [94, 95]; RBANS [103]; }\end{array}$ & 2 \\
\hline Brief Test of Attention [104]; CVLT [105]; CANTAB [106]; CERAD Verbal Learning Test [107]; & 1 \\
\hline \multicolumn{2}{|l|}{ Design Fluency Test [108]; Dichotomous Listening Test [109]; Digit Ordering Test [110]; } \\
\hline \multicolumn{2}{|l|}{ Go/No Go Test [111]; Kohs Cubes Test [112]; Luria Nebraska mental rotation item [113]; } \\
\hline \multicolumn{2}{|l|}{ PPVT [114]; Recurring Figures Test [115]; Road Map Test [116]; Ruff Figural Fluency Test } \\
\hline \multicolumn{2}{|l|}{ [117]; Syndrom Kurz Test [118]; Visual Form Discrimination [119]; Washington Square } \\
\hline \multicolumn{2}{|l|}{ Picture Memory Test [120]; Wisconsin Card Sorting Test [121]; WAIS Letter Number } \\
\hline \multirow{2}{*}{\multicolumn{2}{|c|}{$\begin{array}{l}\text { Sequencing }[94,95] \\
\text { Functional Limitations }\end{array}$}} \\
\hline & \\
\hline UHDRS Total Functional Capacity Scale [18] & 48 \\
\hline UHDRS Functional Assessment Scale [18] & 33 \\
\hline UHDRS Independence Scale [18] & 30 \\
\hline HD Activities of Daily Living (ADL) Scale [32] & 2 \\
\hline \multicolumn{2}{|l|}{ Emotional/Behavioral Functioning } \\
\hline UHDRS Behavioral Exam [18] & 36 \\
\hline Hamilton Depression Rating Scale (Ham-D) [33, 34] & 8 \\
\hline Brief Psychiatric Rating Scale [122] & 7 \\
\hline \multicolumn{2}{|l|}{ Other Assessments } \\
\hline Clinical Global Impression Scale [19] & 13 \\
\hline Clinician Interview Based Impression of Change plus Caregiver [123]; Barthel Index [124]** & 1 \\
\hline Study specific & 1 \\
\hline \multicolumn{2}{|l|}{ PATIENT REPORTED OUTCOMES (PROs) } \\
\hline Beck Depression Inventory (BDI-II) [42] & 6 \\
\hline Epworth Sleepiness Scale [43] & 3 \\
\hline HADS [44] & 2 \\
\hline $\begin{array}{l}\text { NIMH's Self-Rating Score; Connors' Adult ADHD Rating Scale [125]; SIP [126]; SCL-90-R } \\
\text { [127] }\end{array}$ & 1 \\
\hline Study specific & 3 \\
\hline \multicolumn{2}{|l|}{ OBSERVER REPORTED OUTCOMES (ObsRO) } \\
\hline Neuropsychiatric Inventory [128] & 2 \\
\hline $\begin{array}{l}\text { HD-ADL Scale [32]; Activities of Daily Living Scale [129]; Cognitive Behavior Rating Scale } \\
\text { [130] }\end{array}$ & 1 \\
\hline OTHER OUTCOME MEASURES & 46 \\
\hline
\end{tabular}

${ }^{*}=$ Five of these studies only used a single item ( $n=1$ study used the Luria Hand Position Item and $n=4$ studies used the Maximal Chorea Item).

${ }^{* *}=$ The study did not specify if the Barthel Index was administered as a ClinRO or a PRO.

UHDRS Motor Exam [18] was the most frequently used assessment of motor function in HD studies in general, as well as the clinical trials reviewed here (44\% of ClinRO HD assessments used). Although this measure has some noted weaknesses, it has been used extensively in HD clinical trials, and has received a "core" recommendation as a motor functioning measure from the NINDS HD CDE working group [8]. We 


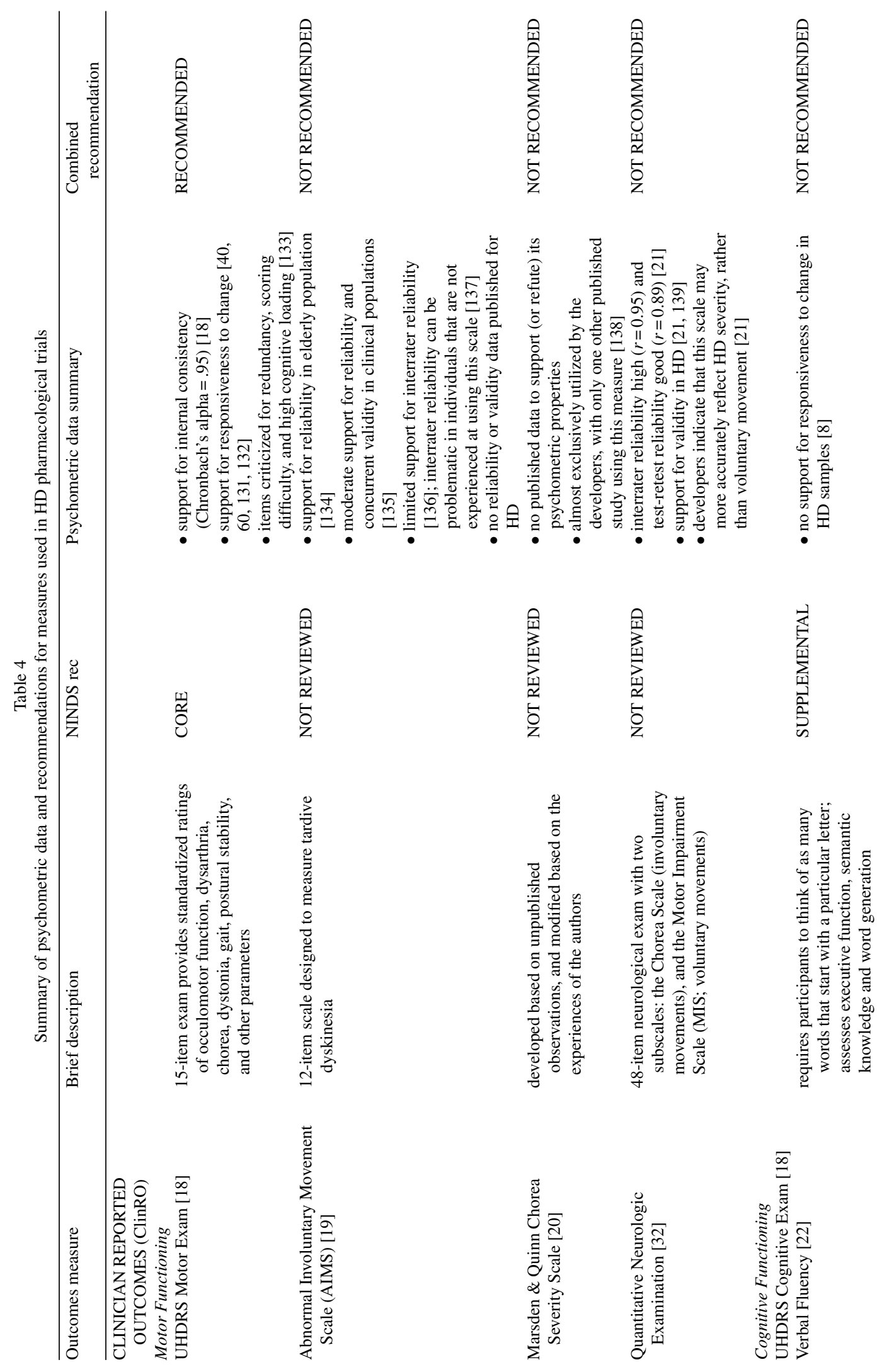




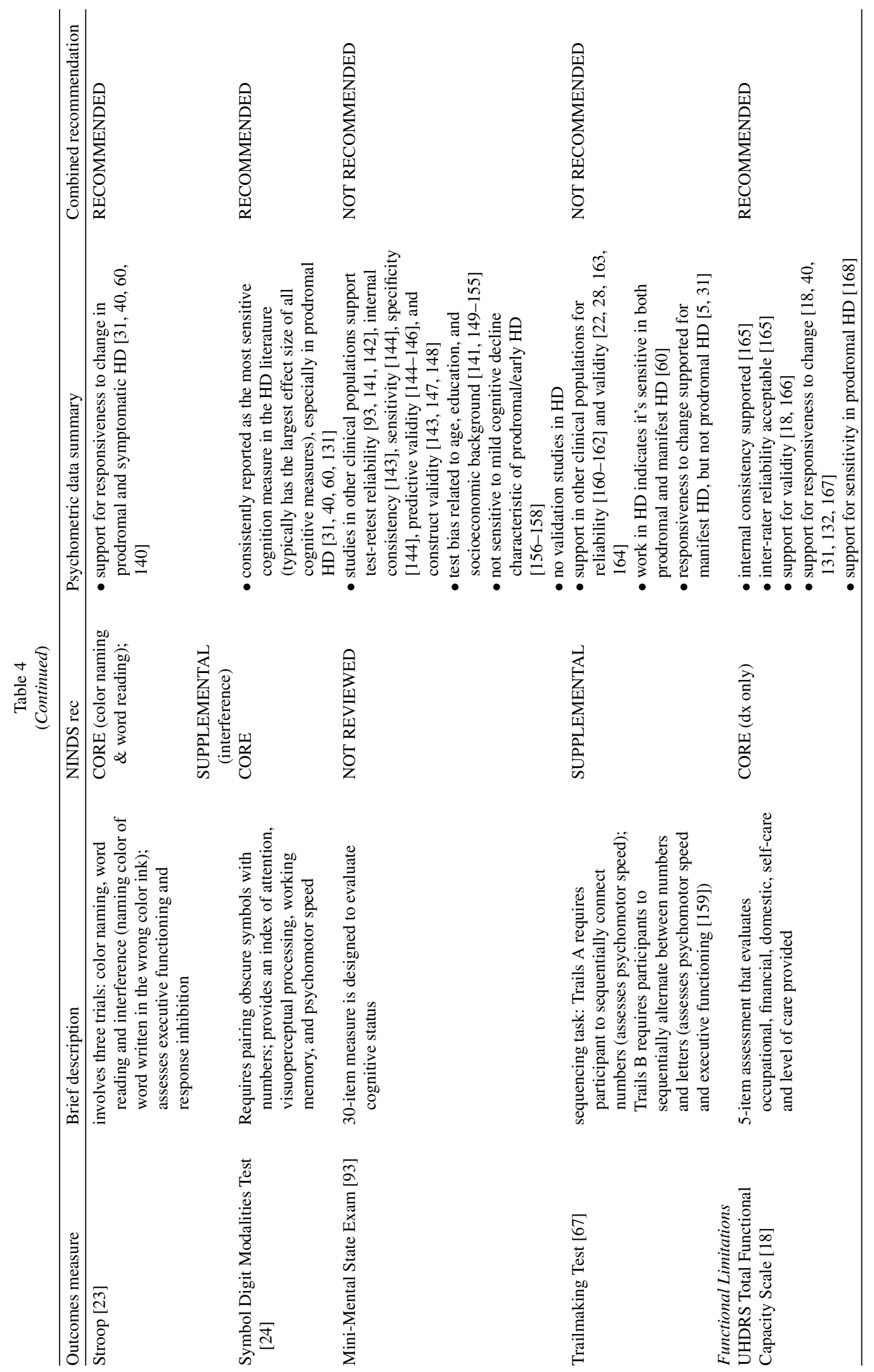


N.E. Carlozzi et al. / Outcomes Measures in HD

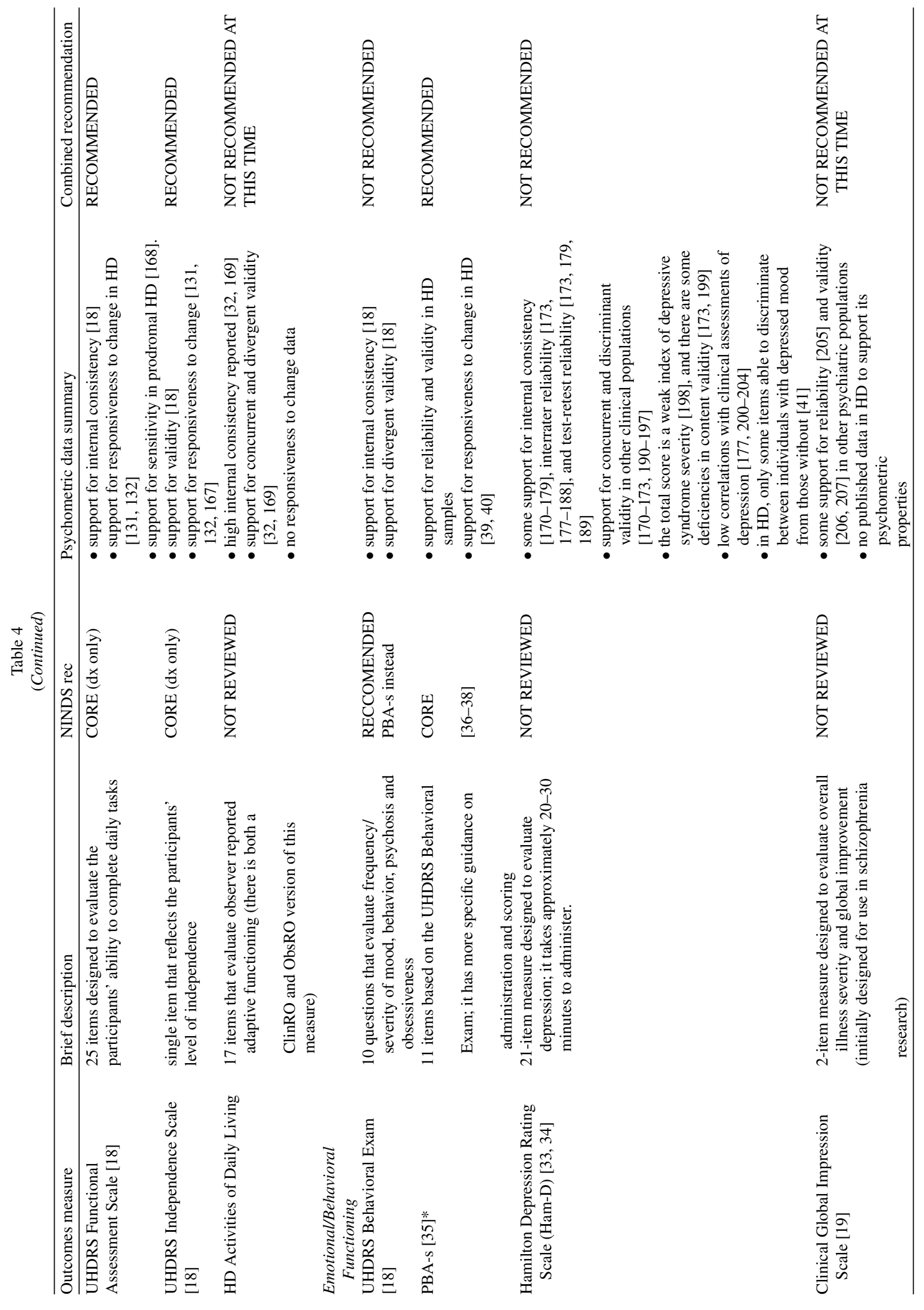




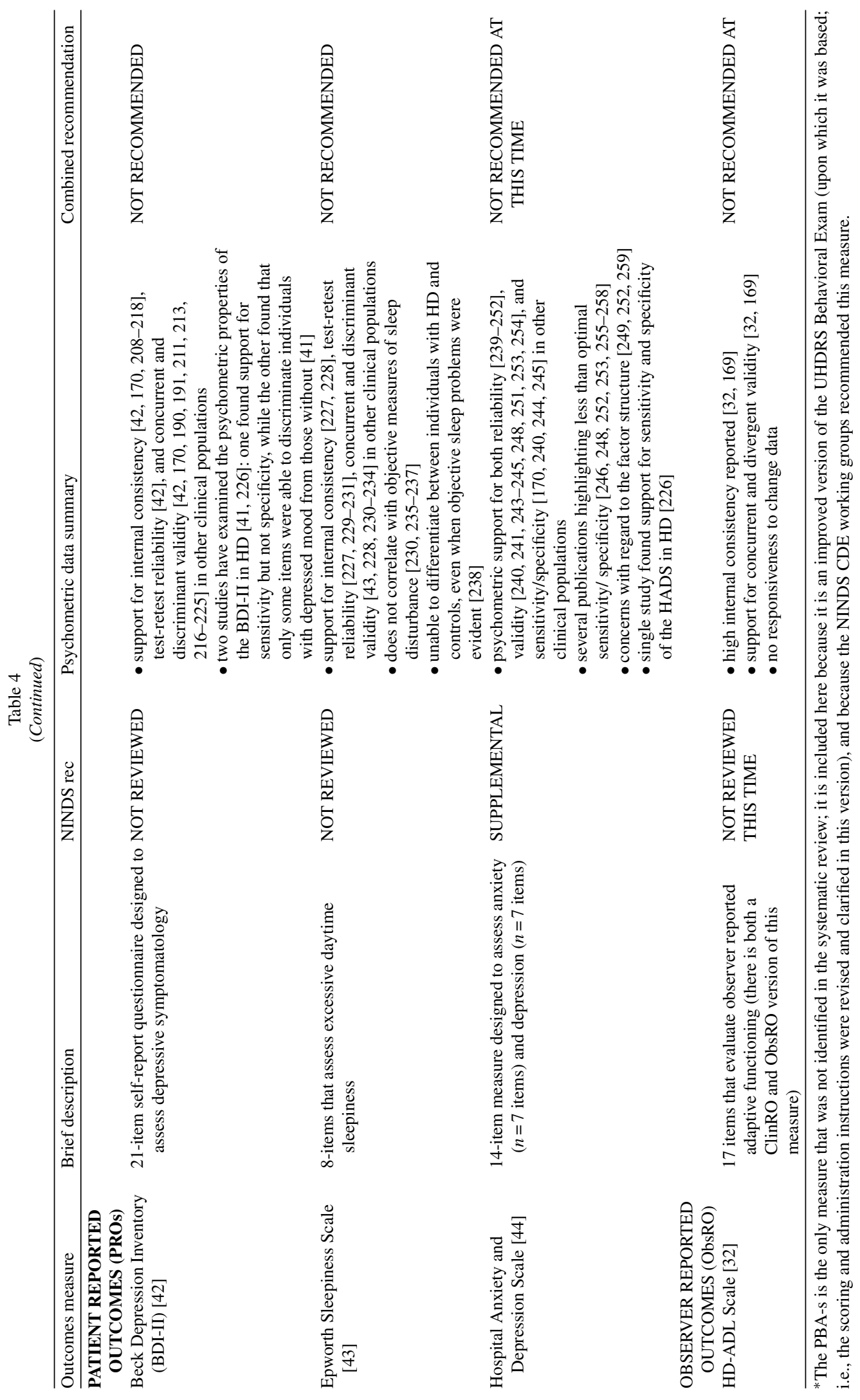


would also recommend this as a reasonable measure for inclusion in HD clinical trials.

Other commonly used ClinRO motor functioning measures are the Abnormal Involuntary Movement Scale (AIMS; $12 \%$ of the ClinRO assessments used) [19], the Marsden \& Quinn Chorea Severity Scale [20] (used in $4 \%$ of the ClinRO assessments) and the Quantitative Neurologic Examination (QNE) [21] (used in three HD clinical trials). None of these three measures was recommended by the NINDS and psychometric support for these measures is lacking. We would not recommend their use in future HD clinical trials (see Table 4).

\section{ClinRO cognitive functioning measures}

Several ClinRO measures include cognitive assessments. As can be seen from Table 3, while many studies utilize cognitive measures, there are several more instances of sole use assessments in this category relative to any other type of measure. Below, we examine measures that have been used in $5 \%$ or more of the HD clinical trials. The three cognitive measures from the UHDRS that have been used with the greatest frequency in HD clinical trials are the Verbal Fluency Test (comprised 33\% of the ClinRO assessments) [22], Stroop (comprised $31 \%$ of the ClinRO assessments used) [23], and Symbol Digit Modalities Test (comprised $27 \%$ of the ClinRO assessments used) [24]. While both the Symbol Digit and Stroop are recommended as core CDEs by the NINDS CDE groups, the verbal fluency test was given a supplemental classification, as it is not sensitive over time in HD samples [8]. We would recommend using the Stroop and the SDMT in HD clinical trials where cognition is the focus of treatment; we do not recommend using Verbal Fluency due both the lack of responsiveness to change data in HD, and the fact that there are other available cognitive measures that have support for responsiveness to change in HD samples.

In addition, the Mini Mental Status Exam (MMSE) was also administered as a measure of cognition for $15 \%$ of the ClinRO assessments, and the Trailmaking test [25] was used in $6 \%$ of the ClinRO assessments. Although there is validation data for the MMSE in other neurological populations [26] and the elderly [27], we were unable to identify published studies validating the MMSE in individuals with HD. The MMSE has been criticized poor discriminability among individuals with cognitive impairments [28, 29], and poor sensitivity to mild cognitive impairments [28, 30]. Thus, the MMSE is not a good candidate measure for inclusion in HD clinical trials. Furthermore, although the Trailmaking test has responsiveness to change for manifest HD, but not prodromal HD [5, 31], it is less desirable for inclusion in HD studies, especially those studies that wish to include the full spectrum of HD severity and/or symptomatology. We do not recommend this measure for use in HD.

\section{ClinRO functional limitations measures}

Several studies have also included measures of functional limitations from the UHDRS [18]: the Total Functional Capacity scale (TFC; included in 34\% of the ClinRO assessments), the Independence Scale (used in $21 \%$ of ClinRO assessments, and the Functional Assessment Scale (included in $24 \%$ of ClinRO assessments). All three of these functional assessments were recommended by the NINDS HD CDE team as core measures in HD research [8], and have strong psychometric support. We recommend them as candidate measures for HD pharmacological trials.

In addition, the Huntington's Disease Activities of Daily Living (HD-ADL) scale was used as a ClinRO assessment in two HD clinical trials [32]. While the developmental validation data suggests that this measure shows promise, additional data on the psychometric properties of this measure are likely needed before it is used consistently in HD research.

\section{ClinRO Emotional/Behavioral functioning measures}

ClinRO measures also include measures of emotional/behavioral functioning. Of note are the UHDRS behavioral exam [18] (used in 26\% of the ClinRO assessments) and the HAM-D [33, 34] (used in 6\% of the ClinRO assessments). While the UHDRS Behavioral Exam [18] includes decent psychometric data, the NINDS CDE group has recommended replacing this with the PBA-s [35] (which is based on the UHDRS behavioral exam, but has more detailed questions, more specific guidance on administration and scoring, and support for its reliability and validity in HD samples [36-38], as well as responsiveness to change over time $[8,39,40])$. We recommend the PBA-s in HD pharmacological trials moving forward.

The Ham-D [33, 34] has also been used in $6 \%$ of the HD ClinRO assessments. While there is some psychometric support for this measure in other clinical populations, there is also some concern. Furthermore, the one study that examined the HAM-D in HD found that although some items discriminated individuals 
with depressed mood from those without, several items could not; the authors therefore concluded that the HAM-D is of limited usefulness in HD [41]. We would not recommend using this measure in HD trials.

\section{ClinRO "Other" assessments}

Finally, 11\% of HD ClinRO assessments included the Clinical Global Impression Scale [19], a measure designed to evaluate overall illness severity and global improvement (initially designed for use in schizophrenia research). As there is no published data in HD to support its psychometric properties, we do not recommend using this measure.

\section{PRO measurements}

The only PROs used in more than a single study were the Beck Depression Inventory Second Edition (BDI-II) [42], Epworth Sleepiness Scale [43] and the Hamilton Anxiety and Depression Scale (HADS) [44]. The Beck Depression Inventory, provides an assessment depressive symptomatology [42]. While there is data to support its psychometric properties in other clinical populations, the two studies have examined the psychometric properties of the BDI-II in HD were not very supportive. Taken together, there is not strong support for the utility of the BDI-II in individuals with HD. While there may be some support for the use of these measures in other clinical populations, the psychometric data for these measures in HD samples is lacking or limited. Furthermore, the NINDS does not make recommendations for any of these measures. We would not recommend these measures for inclusion in future HD clinical trials at this time.

As such, there is a need for PRO measures that have reliability, validity and responsiveness to change data to support their utility in HD pharmacological trials. This message is not new; previous work has highlighted the need for HD-specific PROs measures $[8,45]$. For example, the NINDS CDE PRO working group highlighted a number of potentially useful measures that are either under development or recently developed, but have not yet received widespread use in HD. These include NIH-funded measurement development initiatives: PROMIS ${ }^{\mathrm{TM}}$ (www.nihpromis.org) [46, 47], Neuro-QOL (www.neuroqol.org) [48], and the HDQLIFE ${ }^{\mathrm{TM}}$ [49]. In addition, there are measures that have recently been developed in Europe that might also fill this void (i.e., the HD-Qol [50] and the HD Quality of Life Instrument [51]), although the HD-Qol has been criticized for not meeting statistical assump- tions required for running item response theory [52], and the HD Quality of Life Instrument is only available in French and Italian [52].

Furthermore, since HD is a neurodegenerative condition, individual's in the later stages often exhibit anosognosia, or a lack of insight into one's own symptoms and deficits [53-55]. Anosognosia can compromise the reliability of a PRO, highlighting the importance of capturing information from another source (i.e., ClinRO and/or ObsRO). Thus, a more complete clinical symptom picture requires both types of information: a PRO and a complimentary ClinRO/ObsRO. Taken together there appears to be much work to be done in identifying a universally acceptable, psychometrically sensitive HD-specific PRO measure.

\section{ObsRO measurements}

ObsRO assessments were rarely included in HD clinical trials (only $3 \%$ of the HD clinical trials included and ObsRO measure) highlighting the need for additional work to identify existing measures, or develop new measures that may have utility in HD. One potential candidate for an ObsRo measure might include the HD-ADL Scale [32]; this measure has published ObsRo psychometric data in HD, and with additional work to confirm its psychometric properties, it might be appropriate for use in HD research.

\section{Study limitations}

This review has several limitations. First, to identify outcomes measures that were more likely to be responsive to an intervention, we focused our review on pharmacological/drug trials in HD. In this manner we did not review other experimental, interventional (e.g., non-pharmacological, device based) or observational studies. Therefore, future work is needed to fully evaluate the measures selected for inclusion in other intervention and observational studies, since some of these studies may use other measures that are sensitive to therapeutic effects in HD research. Furthermore, we only extensively reviewed measures that were used with some manner of frequency in HD clinical trials, and therefore, there are several other candidate measures that might have sensitivity in HD that were not evaluated. We also limited our search to clinical trials in English or Spanish and consequently may have missed instruments that are employed in other countries. Furthermore, much recent development work for HD PROs measures is underway, which would not have been captured. 


\section{CONCLUSIONS}

This review provides a summary of the different outcomes measures being used in HD pharmacological trials. ClinRO measures are the most frequent outcomes measures in HD drug studies, and there are psychometric data to support the use of at least a few of these measures as COAs in HD clinical research. Contrary to this, much work still needs to be done before specific recommendations for HD PROs and ObsRO measures are made. To this end, there have been several efforts to develop HD PRO measures, although data are still needed across multiple research groups to support these new measures' reliability, validity and sensitivity to change. Finally, ObsRO measures are lacking; additional development work in this area is needed if we are to utilize these types of measures in our HD pharmacological trials.

\section{ACKNOWLEDGMENTS}

This work was funded by the National Institute of Neurological Disorders and Stroke (NINDS) (Grant Numbers R03NS065194 and 1R01NS077946). The authors also wanted to express appreciation to Whitney Townsend, MLIS, who conducted the systematic literature searches.

\section{CONFLICT OF INTEREST}

The authors have no conflict of interest to report.

\section{SUPPLEMENTARY MATERIAL}

The supplementary tables are available in the electronic version of this article: http://dx.doi.org/10.3233/ JHD-140115.

\section{REFERENCES}

[1] Pringsheim T, Wiltshire K, Day L, Dykeman J, Steeves T, Jette N. The incidence and prevalence of Huntington's disease: A systematic review and meta-analysis. Mov Disord. 2012;27:1083-91.

[2] Paulsen JS. Understanding Behavior in Huntington's Disease. Huntington's Disease Society of America. 1999.

[3] Ho LW, Carmichael J, Swartz J, Wyttenbach A, Rankin J, Rubinsztein DC. The molecular biology of Huntington's disease. Psychol Med. 2001;31:3-14.

[4] Solomon AC, Stout JC, Johnson SA, Langbehn DR, Aylward EH, Brandt J, Ross CA, Beglinger L, Hayden MR, Kieburtz K, Kayson E, Julian-Baros E, Duff K, Guttman M, Nance M, Oakes D, Shoulson I, Penziner E, Paulsen JS. Verbal episodic memory declines prior to diagnosis in Huntington's disease. Neuropsychologia. 2007;45:1767-76.

[5] Tabrizi SJ, Scahill RI, Durr A, Roos RA, Leavitt BR, Jones R, Landwehrmeyer GB, Fox NC, Johnson H, Hicks SL, Kennard C, Craufurd D, Frost C, Langbehn DR, Reilmann R, Stout JC. Biological and clinical changes in premanifest and early stage Huntington's disease in the TRACK-HD study: The 12-month longitudinal analysis. Lancet Neurol. 2011;10:31-42.

[6] Franciosi S, Shim Y, Lau M, Hayden MR, Leavitt BR. A systematic review and meta-analysis of clinical variables used in Huntington disease research. Mov Disord. 2013;28:1987-94.

[7] Langbehn DR, Brinkman RR, Falush D, Paulsen JS, Hayden MR. A new model for prediction of the age of onset and penetrance for Huntington's disease based on CAG length. Clin Genet. 2004;65:267-77.

[8] NINDS CDE Working Group for HD. http://www.common dataelements.ninds.nih.gov/HD.aspx\#tab=Data_Standards

[9] fda.gov. Clinical Outcome Assessment Qualification Program. http://www.fda.gov/Drugs/DevelopmentApproval Process/DrugDevelopmentToolsQualificationProgram/ucm 284077.htm

[10] fda.gov. Clinical Outcome Assessment (COA): Glossary of Terms. http://www.fda.gov/Drugs/DevelopmentApproval Process/DrugDevelopmentToolsQualificationProgram/ucm 370262.htm\#ClinRO

[11] Deckel AW, Morrison D. Evidence of a neurologically based "denial of illness" in patients with Huntington's disease. Arch Clin Neuropsychol. 1996;11:295-302.

[12] Chatterjee A, Anderson KE, Moskowitz CB, Hauser WA, Marder KS. A comparison of self-report and caregiver assessment of depression, apathy, and irritability in Huntington's disease. J Neuropsychiatry Clin Neurosci. 2005; 17:378-83.

[13] Hoth KF, Paulsen JS, Moser DJ, Tranel D, Clark LA, Bechara A. Patients with Huntington's disease have impaired awareness of cognitive, emotional, and functional abilities. J Clin Exp Neuropsychol. 2007;29:365-76.

[14] Duff K, Paulsen JS, Beglinger LJ, Langbehn DR, Wang C, Stout JC, Ross CA, Aylward E, Carlozzi NE, Queller S. "Frontal" behaviors before the diagnosis of Huntington's disease and their relationship to markers of disease progression: Evidence of early lack of awareness. J Neuropsychiatry Clin Neurosci. 2010;22:196-207.

[15] Ho AK, Robbins AO, Barker RA. Huntington's disease patients have selective problems with insight. Mov Disord. 2006;21:385-9.

[16] Snowden JS, Craufurd D, Griffiths HL, Neary D. Awareness of involuntary movements in Huntington disease. Arch Neurol. 1998;55:801-5.

[17] Vitale C, Pellecchia MT, Grossi D, Fragassi N, Cuomo T, Di Maio L, Barone P. Unawareness of dyskinesias in Parkinson's and Huntington's diseases. Neurol Sci. 2001;22: 105-6.

[18] Huntington Study Group. Unified Huntington's Disease Rating Scale: Reliability and consistency. Mov Disord. 1996;11:136-42.

[19] Guy W. ECDEU Assessment Manual for Psychopharmacology: Revised. Rockville, MD: 1976.

[20] Marsden CD, Schachter M. Assessment of extrapyramidal disorders. Br J Clin Pharmacol. 1981;11:129-51.

[21] Folstein SE, Jensen B, Leigh RJ, Folstein MF. The measurement of abnormal movement: Methods developed for Huntington's disease. Neurobehav Toxicol Teratol. 1983;5:605-9. 
[22] Mitrushina M, Boone KB, Rasani J, D’Elia LF. Handbook of normative data for neuropsychological assessment. 2nd. New York: Oxford University Press; 2005.

[23] Stroop JR. Studies of interference in serial verbal reactions. Journal of Experimental Psychology. 1935;18: 643-62.

[24] Smith A. Symbol digit modalities test: Manual. Los Angeles: Western Psychological Services; 1982.

[25] Reitan RM, Wolfson D. The Halstead-Reitan Neuropsychological Test Battery. Theory and Clinical Interpretation. Tuscon: Neuropsychology Press; 1985.

[26] Bridges KW, Goldberg DP. The validation of the GHQ-28 and the use of the MMSE in neurological in-patients. Br J Psychiatry. 1986;148:548-53.

[27] Braekhus A, Laake K, Engedal K. The Mini-Mental State Examination: Identifying the most efficient variables for detecting cognitive impairment in the elderly. J Am Geriatr Soc. 1992;40:1139-45.

[28] Strauss E, Sherman EMS, Spreen O. A compendium of neuropsychological tests: Administration, norms, and commentary. 3rd. Oxford; New York: Oxford University Press; 2006.

[29] Tombaugh TN. Test-retest reliable coefficients and 5-year change scores for the MMSE and 3MS. Arch Clin Neuropsychol. 2005;20:485-503.

[30] Tombaugh TN, McIntyre NJ. The mini-mental state examination: A comprehensive review. J Am Geriatr Soc. 1992;40:922-35.

[31] Stout JC, Jones R, Labuschagne I, O’Regan AM, Say MJ, Dumas EM, Queller S, Justo D, Santos RD, Coleman A, Hart EP, Durr A, Leavitt BR, Roos RA, Langbehn DR, Tabrizi SJ, Frost C. Evaluation of longitudinal 12 and 24 month cognitive outcomes in premanifest and early Huntington's disease. J Neurol Neurosurg Psychiatry. 2012;83:687-94.

[32] Bylsma FW, Rothlind J, Hall MR, Folstein SE, Brandt J. Assessment of adaptive functioning in Huntington's disease. Mov Disord. 1993;8:183-90.

[33] Hamilton M. Development of a rating scale for primary depressive illness. Br J Soc Clin Psychol. 1967;6:278-96.

[34] Hamilton M. A rating scale for depression. J Neurol Neurosurg Psychiatry. 1960;23:56-62.

[35] Craufurd D, Thompson JC, Snowden JS. Behavioral changes in Huntington Disease. Neuropsychiatry Neuropsychol Behav Neurol. 2001;14:219-26.

[36] Kingma EM, van Duijn E, Timman R, van der Mast RC, Roos RA. Behavioural problems in Huntington's disease using the Problem Behaviours Assessment. Gen Hosp Psychiatry. 2008;30:155-61.

[37] Thompson JC, Snowden JS, Craufurd D, Neary D. Behavior in Huntington's disease: Dissociating cognition-based and mood-based changes. J Neuropsychiatry Clin Neurosci. 2002; 14:37-43.

[38] van Duijn E, Giltay EJ, Zitman FG, Roos RAC, van der Mast RC. Measurement of psychopathology in huntington's disease the critical role of caregivers. Journal of Nervous and Mental Disease. 2010;198:329-33.

[39] Thompson JC, Harris J, Sollom AC, Stopford CL, Howard E, Snowden JS, Craufurd D. Longitudinal evaluation of neuropsychiatric symptoms in Huntington's disease. J Neuropsychiatry Clin Neurosci. 2012;24:53-60.

[40] Tabrizi SJ, Reilmann R, Roos RA, Durr A, Leavitt B, Owen G, Jones R, Johnson H, Craufurd D, Hicks SL, Kennard C, Landwehrmeyer B, Stout JC, Borowsky B, Scahill RI, Frost C, Langbehn DR. Potential endpoints for clinical trials in premanifest and early Huntington's disease in the TRACK-
HD study: Analysis of 24 month observational data. Lancet Neurology. 2012;11:42-53.

[41] Rickards H, De Souza J, Crooks J, van Walsem MR, van Duijn E, Landwehrmeyer B, Squitieri F, Simpson SA. Discriminant analysis of Beck Depression Inventory and Hamilton Rating Scale for Depression in Huntington's disease. J Neuropsychiatry Clin Neurosci. 2011;23:399-402.

[42] Beck A, Steer RA, Brown GK. Manual for the Beck-Depression Inventory-II San Antonio, TX: The Psychological Corporation; 1996.

[43] Johns MW. A new method for measuring daytime sleepiness: The Epworth sleepiness scale. Sleep. 1991;14:540-5.

[44] Zigmond AS, Snaith RP. The hospital anxiety and depression scale. Acta Psychiatr Scand. 1983;67:361-70.

[45] Carlozzi NE, Ready RE. Health-related quality of life in Huntington's disease. In: Jenkinson C, Peters M, Bromberg $\mathrm{MB}$, editors. Quality of life measurement in neurodegenerative and related conditions. Cambridge: Cambridge University Press; 2011.

[46] Cella D, Riley W, Stone A, Rothrock N, Reeve B, Yount S, Amtmann D, Bode R, Buysse D, Choi S, Cook K, Devellis R, DeWalt D, Fries JF, Gershon R, Hahn EA, Lai JS, Pilkonis P, Revicki D, Rose M, Weinfurt K, Hays R. The Patient-Reported Outcomes Measurement Information System (PROMIS) developed and tested its first wave of adult self-reported health outcome item banks: 2005-2008. Journal of Clinical Epidemiology. 2010;63:1179-94.

[47] Cella D, Yount S, Rothrock N, Gershon R, Cook K, Reeve B, Ader D, Fries JF, Bruce B, M. R. The Patient-Reported Outcomes Measurement Information System (PROMIS): 567 Progress of an NIH Roadmap cooperative group during its first two years. Medical Care. 2007;45:S3.

[48] Cella DF, Nowinski C, Peterman A, Victorson D, Miller D, Lai J-S, Moy C. The Neurology Quality of Life Measurement (Neuro-QOL) Initiative. Archives of Physical Medicine and Rehabilitation, Supplement. 2011;92:S28S36.

[49] Carlozzi NE, Tulsky DS. Identification of Health-Related Quality of Life (HRQOL) Issues Relevant to Individuals with Huntington Disease. J Health Psychol. 2012;18(2): 212-25.

[50] Hocaoglu MB, Gaffan EA, Ho AK. The Huntington's Disease health-related Quality of Life questionnaire (HDQoL): A disease-specific measure of health-related quality of life. Clin Genet. 2012;81:117-22.

[51] Clay E, De Nicola A, Dorey J, Squitieri F, Aballea S, Martino T, Tedroff J, Zielonka D, Auquier P, Verny C, Toumi M. Validation of the first quality-of-life measurement for patients with Huntington's disease: The Huntington Quality of Life Instrument. Int Clin Psychopharmacol. 2012;27: 208-14.

[52] Paulsen JS, Nance M, Kim J-I, Carlozzi NE, Panegyres PK, Erwin C, Goh AM, McCusker E, Williams JK. A review of quality of life after predictive testing for and earlier identification of neurodegenerative disease. Prog Neurobiol. 2013;110:2-28.

[53] Sitek EJ, Soltan W, Robowski P, Schinwelski M, Wieczorek D, Slawek J. Poor insight into memory impairment in patients with Huntington disease. Neurol Neurochir Pol. 2012;46:318-25.

[54] Sitek EJ, Soltan W, Wieczorek D, Schinwelski M, Robowski P, Harciarek M, Guzinska K, Slawek J. Self-awareness of executive dysfunction in Huntington's disease: Comparison with Parkinson's disease and cervical dystonia. Psychiatry Clin Neurosci. 2013;67:59-62. 
[55] Sitek EJ, Soltan W, Wieczorek D, Schinwelski M, Robowski P, Reilmann R, Guzinska K, Harciarek M, Krysa W, Slawek J. Self-awareness of motor dysfunction in patients with Huntington's disease in comparison to Parkinson's disease and cervical dystonia. J Int Neuropsychol Soc. 2011;17: 788-95.

[56] Gershon RC, Cella D, Fox NA, Havlik RJ, Hendrie HC, Wagster MV. Assessment of neurological and behavioural function: The NIH Toolbox. Lancet Neurol. 2010;9: 138-9.

[57] Rao AK, Muratori L, Louis ED, Moskowitz CB, Marder KS Clinical measurement of mobility and balance impairments in Huntington's disease: Validity and responsiveness. Gait Posture. 2009;29:433-6.

[58] Rao AK, Muratori L, Louis ED, Moskowitz CB, Marder KS Spectrum of gait impairments in presymptomatic and symptomatic Huntington's disease. Mov Disord. 2008;23:1100-7.

[59] Lemay M, Fimbel E, Beuter A, Chouinard S, Richer F. Sensorimotor mapping affects movement correction deficits in early Huntington's disease. Exp Brain Res. 2005;165: 454-60.

[60] Stout JC, Paulsen JS, Queller S, Solomon AC, Whitlock KB, Campbell JC, Carlozzi N, Duff K, Beglinger LJ, Langbehn DR, Johnson SA, Biglan KM, Aylward EH. Neurocognitive signs in prodromal Huntington disease. Neuropsychology. 2011;25:1-14

[61] Johnson SA, Stout JC, Solomon AC, Langbehn DR, Aylward EH, Cruce CB, Ross CA, Nance M, Kayson E, JulianBaros E, Hayden MR, Kieburtz K, Guttman M, Oakes D, Shoulson I, Beglinger L, Duff K, Penziner E, Paulsen JS Beyond disgust: Impaired recognition of negative emotions prior to diagnosis in Huntington's disease. Brain. 2007;130: 1732-44.

[62] Shapiro AM, Benedict RH, Schretlen D, Brandt J. Construct and concurrent validity of the Hopkins Verbal Learning Testrevised. Clinical Neuropsychologist. 1999;13:348-58.

[63] Robertson IH, Ward T, Ridgeway V, Nimmo-Smith I. The structure of normal human attention: The Test of Everyday Attention. J Int Neuropsychol Soc. 1996;2:525-34.

[64] Shepard RN, Metzler J. Mental rotation of threedimensional objects. Science. 1971;171:701-3.

[65] Nasreddine ZS, Phillips NA, Bedirian V, Charbonneau S, Whitehead V, Collin I, Cummings JL, Chertkow H. The Montreal Cognitive Assessment, MoCA: A brief screening tool for mild cognitive impairment. J Am Geriatr Soc. 2005;53:695-9.

[66] Rowe KC, Paulsen JS, Langbehn DR, Duff K, Beglinger LJ, Wang C, O'Rourke JJ, Stout JC, Moser DJ. Self-paced timing detects and tracks change in prodromal Huntington disease. Neuropsychology. 2010;24:435-42.

[67] Reitan RM. The relation of the trail making test to organic brain damage. J Consult Psychol. 1955;19:393-4.

[68] Marin RS, Biedrzycki RC, Firinciogullari S. Reliability and validity of the Apathy Evaluation Scale. Psychiatry Res. 1991;38:143-62.

[69] Starkstein SE, Mayberg HS, Preziosi TJ, Andrezejewski P, Leiguarda R, Robinson RG. Reliability, validity, and clinical correlates of apathy in Parkinson's disease. J Neuropsychiatry Clin Neurosci. 1992;4:134-9.

[70] Posner K, Brown GK, Stanley B, Brent DA, Yershova KV, Oquendo MA, Currier GW, Melvin GA, Greenhill L, Shen S, Mann JJ. The Columbia-Suicide Severity Rating Scale: Initial validity and internal consistency findings from three multisite studies with adolescents and adults. Am J Psychiatry. 2011;168:1266-77.
[71] Trivedi MH, Wisniewski SR, Morris DW, Fava M, Gollan JK, Warden D, Nierenberg AA, Gaynes BN, Husain MM, Luther JF, Zisook S, Rush AJ. Concise Health Risk Tracking scale: A brief self-report and clinician rating of suicidal risk. J Clin Psychiatry. 2011;72:757-64.

[72] Quinn L, Khalil H, Dawes H, Fritz NE, Kegelmeyer D, Kloos AD, Gillard JW, Busse M. Reliability and minimal detectable change of physical performance measures in individuals with pre-manifest and manifest Huntington disease. Phys Ther. 2013;93:942-56.

[73] Corrigan JD, Bogner J. Initial reliability and validity of the Ohio State University TBI Identification Method. J Head Trauma Rehabil. 2007;22:318-29.

[74] Trembath MK, Horton ZA, Tippett L, Hogg V, Collins VR, Churchyard A, Velakoulis D, Roxburgh R, Delatycki MB. A retrospective study of the impact of lifestyle on age at onset of Huntington disease. Mov Disord. 2010;25:1444-50.

[75] Storch EA, Kaufman DA, Bagner D, Merlo LJ, Shapira NA, Geffken GR, Murphy TK, Goodman WK. Florida Obsessive-Compulsive Inventory: Development, reliability, and validity. J Clin Psychol. 2007;63:851-9.

[76] Wilson R, Barnes L, Bennett D. Assessment of lifetime participation in cognitively stimulating activities. J Clin Exp Neuropsychol. 2003;25:634-42.

[77] Burns GL, Keortge SG, Formea GM, Sternberger LG. Revision of the Padua Inventory of obsessive compulsive disorder symptoms: Distinctions between worry, obsessions, and compulsions. Behav Res Ther. 1996;34:163-73.

[78] Vaccarino AL, Sills T, Anderson KE, Endicott J, Giuliano J, Guttman M, Ho AK, Kupchak P, Paulsen JS, Warner JH, Williams J, Evans K. Assessment of day-to-day functioning in prodromal and early Huntington disease. PLoS Curr. 2011;3:RRN1262.

[79] Brossman B, Williams JK, Downing N, Mills JA, Paulsen JS. Development of the Huntington disease work function scale. J Occup Environ Med. 2012;54:1300-8.

[80] EuroQol-a new facility for the measurement of healthrelated quality of life. Health Policy. 1990;16:199-208.

[81] Ho AK, Robbins AO, Walters SJ, Kaptoge S, Sahakian BJ, Barker RA. Health-related quality of life in Huntington's disease: A comparison of two generic instruments, SF-36 and SIP. Mov Disord. 2004;19:1341-8.

[82] Thara R, Rajkumar S, Valecha V. The schedule for assessment of psychiatric disability - a modification of the das-ii. Indian J Psychiatry. 1988;30:47-53.

[83] Ustun TB, Chatterji S, Kostanjsek N, Rehm J, Kennedy C, Epping-Jordan J, Saxena S, von Korff M, Pull C. Developing the World Health Organization Disability Assessment Schedule 2.0. Bull World Health Organ. 2010;88: 815-23.

[84] Goodman AO, Morton AJ, Barker RA. Identifying sleep disturbances in Huntington's disease using a simple diseasefocused questionnaire. PLoS Curr. 2010;2:RRN1189.

[85] Salvini S, Hunter DJ, Sampson L, Stampfer MJ, Colditz GA, Rosner B, Willett WC. Food-based validation of a dietary questionnaire: The effects of week-to-week variation in food consumption. Int J Epidemiol. 1989;18:858-67.

[86] Godin G, Shephard RJ. A simple method to assess exercise behavior in the community. Can J Appl Sport Sci. 1985;10:141-6.

[87] Subar AF, Ziegler RG, Thompson FE, Johnson CC, Weissfeld JL, Reding D, Kavounis KH, Hayes RB. Is shorter always better? Relative importance of questionnaire length and cognitive ease on response rates and data quality for two dietary questionnaires. Am J Epidemiol. 2001;153:404-9. 
[88] Colditz GA, Manson JE, Hankinson SE. The Nurses' Health Study: 20-year contribution to the understanding of health among women. J Womens Health. 1997;6:49-62.

[89] Buysse DJ, Reynolds CF, 3rd, Monk TH, Berman SR, Kupfer DJ. The Pittsburgh Sleep Quality Index: A new instrument for psychiatric practice and research. Psychiatry Res. 1989;28:193-213.

[90] Marinus J, Visser M, van Hilten JJ, Lammers GJ, Stiggelbout AM. Assessment of sleep and sleepiness in Parkinson disease. Sleep. 2003;26:1049-54.

[91] Shoulson I, Fahn S. Huntington disease - clinical care and evaluation. Neurology. 1979;29:1-3.

[92] Simpson GM, Lee JH, Zoubok B, Gardos G. A rating scale for tardive dyskinesia. Psychopharmacology (Berl). 1979;64:171-9.

[93] Folstein MF, Folstein SE, McHugh PR. Mini-mental state. A practical method for grading the cognitive state of patients for the clinician. J Psychiatr Res. 1975;12:189-98.

[94] Wechsler D. Wechsler Adult Intelligence Scale IV. San Antonio: Harcourt Assessment Inc; 2008.

[95] Wechsler D. Wechsler Adult Intelligence Scale III. San Antonio: Harcourt Assessment Inc.; 1997.

[96] Sivan AB. Benton Visual Retention Test. 5th. New York: The Psychological Corporation; 1992.

[97] Hannay HJ, Levin HS. Selective reminding test: An examination of the equivalence of four forms. J Clin Exp Neuropsychol. 1985;7:251-63.

[98] Rosen WG, Mohs RC, Davis KL. A new rating scale for Alzheimer's disease. Am J Psychiatry. 1984;141: 1356-64.

[99] Raven J, Summers B, Birchfield M, Brosier G, Burciaga L, Bykrit B. Manual for Raven's Progressive Matrices and Vocabulary Scales. Reseach Supplement No. 3: A Compendium of North American normative and Validity Studies. Oxford: Oxford Psychologists Press Ltd.; 1990.

[100] Brandt J, Benedict RH. Hopkins verbal learning test-revised. Lutz, FL: Psychological Assessment Resources; 2001.

[101] Wechsler D. Wechsler Memory Scale-Fourth Edition (WMS-IV) technical and interpretive manual. San Antonio, TX: Pearson; 2009

[102] Wechsler D. Wechsler Adult Intelligence Scale-III/Wechsler Memory Scale Third Edition Technical Manual. San Antonio, TX: The Psychological Corporation; 1997.

[103] Randolph C. Repeatable Battery for the Assessment of Neuropsychological Status: Manual. San Antonio, TX: The Psychological Corporation; 1998.

[104] Schretlen D, Bobholz JH, Brandt J. Development and psychometric properties of the Brief Test of Attention. Clinical Neuropsychologist. 1996;10:80-9.

[105] Delis DC, Kramer JH, Kaplan E, Ober BA. California Verbal Learning Test - Second Edition, Adult Version. San Antonio, TX: The Psychological Corporation; 2000.

[106] Sahakian BJ, Owen AM. Computerized assessment in neuropsychiatry using CANTAB: Discussion paper. J R Soc Med. 1992;85:399-402.

[107] Mirra SS, Heyman A, McKeel D, Sumi SM, Crain BJ, Brownlee LM, Vogel FS, Hughes JP, van Belle G, Berg L. The Consortium to Establish a Registry for Alzheimer's Disease (CERAD). Part II. Standardization of the neuropathologic assessment of Alzheimer's disease. Neurology. 1991;41:479-86.

[108] Jones-Gotman M, Milner B. Design fluency: The invention of nonsense drawings after focal cortical lesions. Neuropsychologia. 1977; 15:653-74.
[109] Mohr E, Costa L. Ear asymmetries in dichotic-listening tasks which increase in difficulty. Brain Lang. 1985;24: 233-45.

[110] Cooper JA, Sagar HJ, Jordan N, Harvey NS, Sullivan EV. Cognitive impairment in early, untreated Parkinson's disease and its relationship to motor disability. Brain. 1991;114(Pt 5):2095-122.

[111] Nosek BA, Banaji MR. The go/no-go association task. Social Cogn. 2001;19:161-76.

[112] Stone M. Kohs Block Design Test. In: Keyser DJ, Sweetland RC, editors. Test Critiques II. Kansas City: Test Corporation of America; 1985.

[113] Christensen AL. The Luria Neuropsychological Investigation. New York: Spectrum Press; 1975.

[114] Dunn LM, Dunn DM. Peabody Picture Vocabulary Test Fourth Edition. Minneapolis, MN: NCS Pearson; 2007.

[115] Kimura D. Right temporal-lobe damage. Perception of unfamiliar stimuli after damage. Arch Neurol. 1963;8:264-71.

[116] Money J, Alexander D, Walker HT. A standardized road map test of direction sense. Percept Motor Skills. 1965;21: 331.

[117] Ruff RM. Ruff Figural Fluency Test professional manual. Odessa, FL: Psychological Assessment Resources; 1988.

[118] Overall JE, Schaltenbrand R. The SKT neuropsychological test battery. J Geriatr Psychiatry Neurol. 1992;5:220-7.

[119] Benton AL, Sivan AB, Hamsher KD, Varney NR, Spreen O. Contributions to neuropsychological assessment. Second Edition. New York: Oxford University Press; 1994.

[120] Corwin J, G. SJ. Instructions for the Picture Memory Test. New York: Washington Square Associates; 1985.

[121] Nelson HE. A modified card sorting test sensitive to frontal lobe defects. Cortex. 1976;12:313-24.

[122] Overall JE, Gorham DR. The Brief Psychiatric Rating Scale (BPRS): A comprehensive review. J Operational Psychiatry. 1962;11:48-65.

[123] Joffres C, Graham J, Rockwood K. Qualitative analysis of the clinician interview-based impression of change (Plus): Methodological issues and implications for clinical research. Int Psychogeriatr. 2000;12:403-13.

[124] Mahoney FI, Barthel DW. Functional evaluation: The barthel index. Md State Med J. 1965;14:61-5.

[125] Conners CK, Erhardt D, Sparrow E. Conner's Adult ADHD Rating Scales (CAARS). Technical manual. North Tonawanda, NY: Multi-Health Systems; 1999.

[126] Bergner M, Bobbitt RA, Carter WB, Gilson BS. The Sickness Impact Profile: Development and final revision of a health status measure. Medical Care. 1981;19:787805.

[127] Derogatis LR. Symptom Checklist-90-R (SCL-90-R). Minneapolis, MN: NCS Assessments; 1975.

[128] Cummings JL, Mega M, Gray K, Rosenberg-Thompson S, Carusi DA, Gornbein J. The Neuropsychiatric Inventory: Comprehensive assessment of psychopathology in dementia. Neurology. 1994;44:2308-14.

[129] Galasko D, Bennett D, Sano M, Ernesto C, Thomas R, Grundman M, Ferris S. An inventory to assess activities of daily living for clinical trials in Alzheimer's disease. The Alzheimer's Disease Cooperative Study. Alzheimer Dis Assoc Disord. 1997;11(Suppl 2):S33-9.

[130] Williams JM. Cognitive behavioral rating scales: Research edition. Odessa, FL: Psychological Assessment Resources, Inc.; 1990.

[131] Siesling S, van Vugt JP, Zwinderman KA, Kieburtz K, Roos RA. Unified Huntington's disease rating scale: A follow up. Mov Disord. 1998;13:915-9. 
[132] Zielonka D, Marinus J, Roos RA, De Michele G, Di Donato S, Putter H, Marcinkowski J, Squitieri F, Bentivoglio AR, Landwehrmeyer GB. The influence of gender on phenotype and disease progression in patients with Huntington's disease. Parkinsonism Relat Disord. 2013;19:192-7.

[133] Siesling S, Zwinderman AH, van Vugt JP, Kieburtz K, Roos RA. A shortened version of the motor section of the Unified Huntington's Disease Rating Scale. Mov Disord. 1997; 12:229-34.

[134] Sweet RA, DeSensi EG, Zubenko GS. Reliability and applicability of movement disorder rating scales in the elderly. $\mathrm{J}$ Neuropsychiatry Clin Neurosci. 1993;5:56-60.

[135] Koning JP, Tenback DE, Kahn RS, Van Schelven LJ, Van Harten PN. Instrument measurement of lingual force variability reflects tardive tongue dyskinesia. J Med Eng Technol. 2010;34:71-7.

[136] Barnes TR, Trauer T. Reliability and validity of a tardive dyskinesia videotape rating technique. Br J Psychiatry. 1982;140:508-15.

[137] Lane RD, Glazer WM, Hansen TE, Berman WH, Kramer SI. Assessment of tardive dyskinesia using the Abnormal Involuntary Movement Scale. J Nerv Ment Dis. 1985;173: 353-7.

[138] De Tommaso M, Difruscolo O, Sciruicchio V, Specchio N, Livrea P. Two years' follow-up of rivastigmine treatment in Huntington disease. Clin Neuropharmacol. 2007;30: 43-6.

[139] Rosenblatt A, Abbott MH, Gourley LM, Troncoso JC, Margolis RL, Brandt J, Ross CA. Predictors of neuropathological severity in 100 patients with Huntington's disease. Ann Neurol. 2003;54:488-93.

[140] Bamford KA, Caine ED, Kido DK, Cox C, Shoulson I. A prospective evaluation of cognitive decline in early Huntington's disease: Functional and radiographic correlates. Neurology. 1995;45:1867-73.

[141] Anthony JC, Leresche L, Niaz U, Vonkorff MR, Folstein MF. Limits of the Mini-Mental State as a screening-test for dementia and delirium among hospital patients. Psychol Med. 1982;12:397-408.

[142] Dick JP, Guiloff RJ, Stewart A, Blackstock J, Bielawska C, Paul EA, Marsden CD. Mini-mental state examination in neurological patients. J Neurol Neurosurg Psychiatry. 1984;47:496-9.

[143] McDowell I, Kristjansson B, Hill GB, Hebert R. Community screening for dementia: The Mini Mental State Exam (MMSE) and Modified Mini-Mental State Exam (3MS) compared. J Clin Epidemiol. 1997;50:377-83.

[144] Paquay L, De Lepeleire J, Schoenmakers B, Ylieff M, Fontaine O, Buntinx F. Comparison of the diagnostic accuracy of the Cognitive Performance Scale (Minimum Data Set) and the Mini-Mental State Exam for the detection of cognitive impairment in nursing home residents. Int J Geriatr Psychiatry. 2007;22:286-93.

[145] Ford GR, Haley WE, Thrower SL, West CA, Harrell LE. Utility of Mini-Mental State Exam scores in predicting functional impairment among white and African American dementia patients. J Gerontol A Biol Sci Med Sci. 1996;51:M185-8

[146] Burker EJ, Blumenthal JA, Feldman M, Thyrum E, Mahanna E, White W, Smith LR, Lewis J, Croughwell N, Schell R, Newman M, Reves JG. The Mini-Mental-State-Exam as a predictor of neuropsychological functioning after cardiacsurgery. Int J Psychiatry Med. 1995;25:263-76.

[147] Ala TA, Hughes LF, Kyrouac GA, Ghobrial MW, Elble RJ. The Mini-Mental State exam may help in the differentiation of dementia with Lewy bodies and Alzheimer's disease. Int J Geriatr Psychiatry. 2002;17:503-9.

[148] Hughes LF, Perkins K, Wright BD, Westrick H. Using a Rasch scale to characterize the clinical features of patients with a clinical diagnosis of uncertain, probable, or possible Alzheimer disease at intake. J Alzheimers Dis. 2003;5:36773.

[149] Jorm AF, Scott R, Henderson AS, Kay DWK. Educationallevel differences on the Mini-Mental State - the role of test bias. Psychol Med. 1988;18:727-31.

[150] Murden RA, McRae TD, Kaner S, Bucknam ME. MiniMental State exam scores vary with education in blacks and whites. J Am Geriatr Soc. 1991;39:149-55.

[151] Espino DV, Lichtenstein MJ, Palmer RF, Hazuda HP. Ethnic differences in mini-mental state examination (MMSE) scores: Where you live makes a difference. J Am Geriatr Soc. 2001;49:538-48.

[152] Black SA, Espino DV, Mahurin R, Lichtenstein MJ, Hazuda HP, Fabrizio D, Ray LA, Markides KS. The influence of noncognitive factors on the Mini-Mental State Examination in older Mexican-Americans: Findings from the Hispanic EPESE. Established Population for the Epidemiologic Study of the Elderly. J Clin Epidemiol. 1999;52:1095-102.

[153] Brayne C, Calloway P. The association of education and socioeconomic status with the Mini Mental State Examination and the clinical diagnosis of dementia in elderly people. Age Ageing. 1990;19:91-6.

[154] Anthony J, Folstein M, Kramer M. Limits of the MiniMental State as a screen for severe cognitive impairment in the community. Am J Epidemiol. 1985;122:545.

[155] Fillenbaum GG, Hughes DC, Heyman A, George LK, Blazer DG. Relationship of health and demographic characteristics to Mini-Mental State examination score among community residents. Psychol Med. 1988;18:719-26.

[156] Srivastava A, Rapoport MJ, Leach L, Phillips A, Shammi $\mathrm{P}$, Feinstein A. The utility of the mini-mental status exam in older adults with traumatic brain injury. Brain Inj. 2006;20:1377-82.

[157] Swirsky-Sacchetti T, Field HL, Mitchell DR, Seward J, Lublin FD, Knobler RL, Gonzalez CF. The sensitivity of the Mini-Mental State Exam in the white matter dementia of multiple sclerosis. J Clin Psychol. 1992;48:779-86.

[158] McDougall GJ. A review of screening instruments for assessing cognition and mental status in older adults. Nurse Pract. 1990;15:18-28.

[159] Lezak MD. Neuropsychological assessment. 3rd. New York: Oxford University Press; 1995.

[160] Dikmen SS, Heaton RK, Grant I, Temkin NR. Test-retest reliability and practice effects of expanded Halstead-Reitan Neuropsychological Test Battery. J Int Neuropsychol Soc. 1999;5:346-56.

[161] Bornstein RA, Baker GB, Douglass AB. Short-term retest reliability of the Halstead-Reitan Battery in a normal sample. J Nerv Ment Dis. 1987;175:229-32.

[162] Matarazzo JD, Wiens AN, Matarazzo RG, Goldstein SG. Psychometric and clinical test-retest reliability of the Halstead impairment index in a sample of healthy, young, normal men. J Nerv Ment Dis. 1974; 158:37-49.

[163] Storandt M, Botwinick J, Danziger WL, Berg L, Hughes CP. Psychometric differentiation of mild senile dementia of the Alzheimer type. Arch Neurol. 1984;41:497-9.

[164] Goldman WP, Baty JD, Buckles VD, Sahrmann S, Morris JC. Cognitive and motor functioning in Parkinson disease: Subjects with and without questionable dementia. Arch Neurol. 1998;55:674-80. 
[165] Shoulson I, Kurlan R, Rubin AJ. Assessment of functional capacity in neurodegenerative movement disorders: Huntington's disease as a prototype. In: Munsat TL, editors. Quantification of Neurological Deficit. Boston: Butterworths; 1989, pp. 271-283.

[166] Young AB, Penney JB, Starosta-Rubinstein S, Markel DS, Berent S, Giordani B, Ehrenkaufer R, Jewett D, Hichwa R. PET scan investigations of Huntington's disease: Cerebral metabolic correlates of neurological features and functional decline. Ann Neurol. 1986;20:296-303.

[167] Marder K, Zhao H, Myers RH, Cudkowicz M, Kayson E, Kieburtz K, Orme C, Paulsen J, Penney JB, Jr, Siemers E, Shoulson I. Rate of functional decline in Huntington's disease. Huntington Study Group. Neurology. 2000;54:452-8.

[168] Beglinger LJ, O'Rourke JJ, Wang C, Langbehn DR, Duff $\mathrm{K}$, Paulsen JS. Earliest functional declines in Huntington disease. Psychiatry Res. 2010;178:414-8.

[169] Rothlind JC, Bylsma FW, Peyser C, Folstein SE, Brandt J. Cognitive and motor correlates of everyday functioning in early Huntington's disease. J Nerv Ment Dis. 1993;181:1949.

[170] Aben I, Verhey F, Lousberg R, Lodder J, Honig A. Validity of the beck depression inventory, hospital anxiety and depression scale, SCL-90, and hamilton depression rating scale as screening instruments for depression in stroke patients. Psychosomatics. 2002;43:386-93.

[171] Gencoz F, Gencoz T, Soykan A. Psychometric properties of the Hamilton Depression Rating Scale and other physicianrated psychiatric scales for the assessment of depression in ESRD patients undergoing hemodialysis in Turkey. Psychol Health Med. 2007;12:450-9.

[172] Riskind JH, Beck AT, Brown G, Steer RA. Taking the measure of anxiety and depression. Validity of the reconstructed Hamilton scales. J Nerv Ment Dis. 1987;175:474-9.

[173] Bagby RM, Ryder AG, Schuller DR, Marshall MB. The Hamilton Depression Rating Scale: Has the gold standard become a lead weight? Am J Psychiatry. 2004;161:2163-77.

[174] Meyer JS, Li YS, Thornby J. Validating mini-mental status, cognitive capacity screening and Hamilton depression scales utilizing subjects with vascular headaches. Int J Geriatr Psychiatry. 2001;16:430-5.

[175] Middelboe T, Ovesen L, Mortensen EL, Bech P. Depressive symptoms in cancer patients undergoing chemotherapy: A psychometric analysis. Psychother Psychosom. 1994;61:171-7.

[176] Ramos-Brieva JA, Cordero-Villafafila A. A new validation of the Hamilton Rating Scale for Depression. J Psychiatr Res. 1988;22:21-8

[177] Rehm LP, O'Hara MW. Item characteristics of the Hamilton Rating Scale for Depression. J Psychiatr Res. 1985;19:3141.

[178] Fuglum E, Rosenberg C, Damsbo N, Stage K, Lauritzen L, Bech P. Screening and treating depressed patients. A comparison of two controlled citalopram trials across treatment settings: Hospitalized patients vs. patients treated by their family doctors. Danish University Antidepressant Group. Acta Psychiatr Scand. 1996;94:18-25.

[179] Trajkovic G, Starcevic V, Latas M, Lestarevic M, Ille T, Bukumiric Z, Marinkovic J. Reliability of the Hamilton Rating Scale for Depression: A meta-analysis over a period of 49 years. Psychiatry Res. 2011;189:1-9.

[180] Addington D, Addington J, Schissel B. A depression rating scale for schizophrenics. Schizophr Res. 1990;3:247-51.

[181] Addington D, Addington J, Atkinson M. A psychometric comparison of the Calgary Depression Scale for Schizophre- nia and the Hamilton Depression Rating Scale. Schizophr Res. 1996;19:205-12.

[182] Baca-Garcia E, Blanco C, Saiz-Ruiz J, Rico F, Diaz-Sastre C, Cicchetti DV. Assessment of reliability in the clinical evaluation of depressive symptoms among multiple investigators in a multicenter clinical trial. Psychiatry Res. 2001;102:163-73.

[183] Craig TJ, Richardson MA, Pass R, Bregman Z. Measurement of mood and affect in schizophrenic inpatients. The American Journal of Psychiatry. 1985;142:1272-7.

[184] Deluty BM, Deluty RH, Carver CS. Concordance between clinicians' and patients' ratings of anxiety and depression as mediated by private self-consciousness. J Pers Assess. 1986;50:93-106.

[185] Koenig HG, Pappas P, Holsinger T, Bachar JR. Assessing diagnostic approaches to depression in medically ill older adults - how reliably can mental-health professionals make judgments about the cause of symptoms. J Am Geriatr Soc. 1995;43:472-8.

[186] Maier W, Philipp M, Heuser I, Schlegel S, Buller R, Wetzel H. Improving depression severity assessment-I. Reliability, internal validity and sensitivity to change of three observer depression scales. J Psychiatr Res. 1988;22:3-12.

[187] McAdams LA, Harris MJ, Bailey A, Fell R, Jeste DV. Validating specific psychopathology scales in older outpatients with schizophrenia. J Nerv Ment Dis. 1996;184:246-51.

[188] Pancheri P, Picardi A, Pasquini M, Gaetano P, Biondi M. Psychopathological dimensions of depression: A factor study of the 17-item Hamilton depression rating scale in unipolar depressed outpatients. J Affect Disord. 2002;68:41-7.

[189] Williams JB. A structured interview guide for the Hamilton Depression Rating Scale. Arch Gen Psychiatry. 1988;45:742-7.

[190] Moran PJ, Mohr DC. The validity of Beck Depression Inventory and Hamilton Rating Scale for Depression items in the assessment of depression among patients with multiple sclerosis. J Behav Med. 2005;28:35-41.

[191] Kang HJ, Stewart R, Kim JM, Jang JE, Kim SY, Bae KY, Kim SW, Shin IS, Park MS, Cho KH, Yoon JS. Comparative validity of depression assessment scales for screening poststroke depression. J Affect Disord. 2012;147(1-3): 186-91.

[192] Serrano-Duenas M, Soledad Serrano M. Concurrent validation of the 21-item and 6-item Hamilton Depression Rating Scale versus the DSM-IV diagnostic criteria to assess depression in patients with Parkinson's disease: An exploratory analysis. Parkinsonism Relat Disord. 2008; 14:233-8.

[193] Naarding P, Leentjens AF, van Kooten F, Verhey FR. Disease-specific properties of the Rating Scale for Depression in patients with stroke, Alzheimer's dementia, and Parkinson's disease. J Neuropsychiatry Clin Neurosci. 2002;14:329-34.

[194] Leentjens AF, Verhey FR, Lousberg R, Spitsbergen $\mathrm{H}$, Wilmink FW. The validity of the Hamilton and Montgomery-Asberg depression rating scales as screening and diagnostic tools for depression in Parkinson's disease. Int J Geriatr Psychiatry. 2000;15:644-9.

[195] Bech P, Allerup P, Maier W, Albus M, Lavori P, Ayuso JL. The Hamilton scales and the Hopkins Symptom Checklist (SCL-90). A cross-national validity study in patients with panic disorders. Br J Psychiatry. 1992;160:206-11.

[196] Knesevich JW, Biggs JT, Clayton PJ, Ziegler VE. Validity of the Hamilton Rating Scale for depression. Br J Psychiatry. 1977; $131: 49-52$ 
[197] Stage KB, Middelboe T, Pisinger C. Measurement of depression in patients with chronic obstructive pulmonary disease (COPD). Nord J Psychiatry. 2003;57:297-301.

[198] Gibbons RD, Clark DC, Kupfer DJ. Exactly what does the Hamilton Depression Rating Scale measure? J Psychiatr Res. 1993;27:259-73.

[199] Maier W, Heuser I, Philipp M, Frommberger U, Demuth W. Improving depression severity assessment-II. Content, concurrent and external validity of three observer depression scales. J Psychiatr Res. 1988;22:13-9.

[200] Montgomery SA, Asberg M. A new depression scale designed to be sensitive to change. $\mathrm{Br} \mathrm{J}$ Psychiatry. 1979;134:382-9.

[201] Bech P, Allerup P, Reisby N, Gram LF. Assessment of symptom change from improvement curves on the Hamilton depression scale in trials with antidepressants. Psychopharmacology (Berl). 1984;84:276-81.

[202] Kearns NP, Cruickshank CA, McGuigan KJ, Riley SA, Shaw SP, Snaith RP. A comparison of depression rating scales. Br J Psychiatry. 1982;141:45-9.

[203] Maier W, Philipp M, Gerken A. Dimensions of the Hamilton Depression Scale. Factor analysis studies. Eur Arch Psychiatry Neurol Sci. 1985;234:417-22.

[204] Bech P, Allerup P, Gram LF, Reisby N, Rosenberg R, Jacobsen O, Nagy A. The Hamilton depression scale. Evaluation of objectivity using logistic models. Acta Psychiatr Scand. 1981;63:290-9.

[205] Dahlke F, Lohaus A, Gutzmann H. Reliability and clinical concepts underlying global judgments in dementia: Implications for clinical research. Psychopharmacol Bull. 1992;28:425-32.

[206] Berk M, Ng F, Dodd S, Callaly T, Campbell S, Bernardo $\mathrm{M}$, Trauer T. The validity of the CGI severity and improvement scales as measures of clinical effectiveness suitable for routine clinical use. J Eval Clin Pract. 2008;14:979-83.

[207] Zaider TI, Heimberg RG, Fresco DM, Schneier FR, Liebowitz MR. Evaluation of the clinical global impression scale among individuals with social anxiety disorder. Psychol Med. 2003;33:611-22.

[208] Hall BJ, Hood MM, Nackers LM, Azarbad L, Ivan I, Corsica J. Confirmatory factor analysis of the Beck Depression Inventory-II in bariatric surgery candidates. Psychol Assess. 2013;25:294-9

[209] Beck AT, Steer RA, Ball R, Ranieri W. Comparison of Beck Depression Inventories -IA and -II in psychiatric outpatients. J Pers Assess. 1996;67:588-97.

[210] Lopez MN, Pierce RS, Gardner RD, Hanson RW. Standardized Beck Depression Inventory-II scores for male veterans coping with chronic pain. Psychol Serv. 2012;10(2): 257-63.

[211] Lipps GE, Lowe GA, De La Haye W, Longman-Mills S, Clarke TR, Barton EN, Bain B. Validation of the Beck Depression Inventory II in HIV-positive patients. West Indian Med J. 2010;59:374-9.

[212] Harris CA, D'Eon JL. Psychometric properties of the Beck Depression Inventory-second edition (BDI-II) in individuals with chronic pain. Pain. 2008;137:609-22.

[213] Levin BE, Llabre MM, Weiner WJ. Parkinson's disease and depression: Psychometric properties of the Beck Depression Inventory. J Neurol Neurosurg Psychiatry. 1988;51: 1401-4.

[214] Grothe KB, Dutton GR, Jones GN, Bodenlos J, Ancona M, Brantley PJ. Validation of the Beck Depression InventoryII in a low-income African American sample of medical outpatients. Psychol Assess. 2005;17:110-4.
[215] Steer RA, Rissmiller DJ, Beck AT. Use of the Beck Depression Inventory-II with depressed geriatric inpatients. Behav Res Ther. 2000;38:311-8.

[216] Chemerinski E, Bowie C, Anderson H, Harvey PD. Depression in schizophrenia: Methodological artifact or distinct feature of the illness? J Neuropsychiatry Clin Neurosci. 2008;20:431-40.

[217] Joe S, Woolley ME, Brown GK, Ghahramanlou-Holloway M, Beck AT. Psychometric properties of the Beck Depression Inventory-II in low-income, African American suicide attempters. J Pers Assess. 2008;90:521-3.

[218] Osman A, Kopper BA, Barrios F, Gutierrez PM, Bagge CL. Reliability and validity of the Beck depression inventory-II with adolescent psychiatric inpatients. Psychol Assess. 2004;16:120-32.

[219] Krefetz DG, Steer RA, Gulab NA, Beck AT. Convergent validity of the Beck depression inventory-II with the reynolds adolescent depression scale in psychiatric inpatients. J Pers Assess. 2002;78:451-60.

[220] Arnau RC, Meagher MW, Norris MP, Bramson R. Psychometric evaluation of the Beck Depression Inventory-II with primary care medical patients. Health Psychol. 2001;20:112-9.

[221] Steer RA, Ball R, Ranieri WF, Beck AT. Further evidence for the construct validity of the Beck depression Inventory-II with psychiatric outpatients. Psychol Rep. 1997;80:443-6.

[222] Hammash MH, Hall LA, Lennie TA, Heo S, Chung ML, Lee KS, Moser DK. Psychometrics of the PHQ-9 as a measure of depressive symptoms in patients with heart failure. Eur $\mathbf{J}$ Cardiovasc Nurs. 2012;12(5):446-53.

[223] Brown M, Kaplan C, Jason L. Factor analysis of the Beck Depression Inventory-II with patients with chronic fatigue syndrome. J Health Psychol. 2012;17:799-808.

[224] Konig HH, Born A, Gunther O, Matschinger H, Heinrich S, Riedel-Heller SG, Angermeyer MC, Roick C. Validity and responsiveness of the EQ-5D in assessing and valuing health status in patients with anxiety disorders. Health Qual Life Outcomes. 2010;8:47.

[225] Schotte CK, Maes M, Cluydts R, De Doncker D, Cosyns P. Construct validity of the Beck Depression Inventory in a depressive population. J Affect Disord. 1997;46:115-25.

[226] De Souza J, Jones LA, Rickards H. Validation of self-report depression rating scales in Huntington's disease. Mov Disord. 2010;25:91-6.

[227] Johns MW. Reliability and factor analysis of the Epworth Sleepiness Scale. Sleep. 1992;15:376-81.

[228] Baumgartel KL, Terhorst L, Conley YP, Roberts JM. Psychometric evaluation of the Epworth Sleepiness Scale in an obstetric population. Sleep Med. 2013;14:116-121.

[229] Broderick JE, Junghaenel DU, Schneider S, Pilosi JJ, Stone AA. Pittsburgh and Epworth sleep scale items: Accuracy of ratings across different reporting periods. Behav Sleep Med. 2013;11:173-88.

[230] Kaminska M, Jobin V, Mayer P, Amyot R, Perraton-Brillon M, Bellemare F. The Epworth Sleepiness Scale: Selfadministration versus administration by the physician, and validation of a French version. Can Respir J. 2010;17:e27-34.

[231] Massie CA, Hart RW. Clinical outcomes related to interface type in patients with obstructive sleep apnea/hypopnea syndrome who are using continuous positive airway pressure. Chest. 2003;123:1112-8.

[232] Johns MW. Sensitivity and specificity of the multiple sleep latency test (MSLT), the maintenance of wakefulness test and the epworth sleepiness scale: Failure of the MSLT as a gold standard. J Sleep Res. 2000;9:5-11. 
[233] Ulander M, Arestedt K, Svanborg E, Johansson P, Brostrom A. The fairness of the Epworth Sleepiness Scale: Two approaches to differential item functioning. Sleep Breath. 2013; $17: 157-165$.

[234] Hagell P, Broman JE. Measurement properties and hierarchical item structure of the Epworth Sleepiness Scale in Parkinson's disease. J Sleep Res. 2007;16:102-9.

[235] Sauter C, Asenbaum S, Popovic R, Bauer H, Lamm C, Klosch G, Zeitlhofer J. Excessive daytime sleepiness in patients suffering from different levels of obstructive sleep apnoea syndrome. J Sleep Res. 2000;9:293-301.

[236] Neau JP, Paquereau J, Auche V, Mathis S, Godeneche G, Ciron J, Moinot N, Bouche G. Sleep disorders and multiple sclerosis: A clinical and polysomnography study. Eur Neurol. 2012;68:8-15.

[237] Chervin RD, Aldrich MS. The Epworth Sleepiness Scale may not reflect objective measures of sleepiness or sleep apnea. Neurology. 1999;52:125-31.

[238] Goodman AO, Rogers L, Pilsworth S, McAllister CJ, Shneerson JM, Morton AJ, Barker RA. Asymptomatic sleep abnormalities are a common early feature in patients with Huntington's disease. Curr Neurol Neurosci Rep. 2011;11:211-7.

[239] Vallejo MA, Rivera J, Esteve-Vives J, Rodriguez-Munoz MF. Use of the Hospital Anxiety and Depression Scale (HADS) to evaluate anxiety and depression in fibromyalgia patients. Rev Psiquiatr Salud Ment. 2012;5:107-114.

[240] Marcolino JA, Mathias LA, Piccinini Filho L, Guaratini AA, Suzuki FM, Alli LA. Hospital Anxiety and Depression Scale: A study on the validation of the criteria and reliability on preoperative patients. Rev Bras Anestesiol. 2007;57:52-62.

[241] Falavigna A, Righesso O, Teles AR, Baseggio N, Velho MC, Ruschel LG, Abruzzi F, Silva PG. Depression subscale of the hospital anxiety and depression scale applied preoperatively in spinal surgery. Arq Neuropsiquiatr. 2012;70:352-6.

[242] Leentjens AF, Dujardin K, Marsh L, Richard IH, Starkstein SE, Martinez-Martin P. Anxiety rating scales in Parkinson's disease: A validation study of the Hamilton anxiety rating scale, the Beck anxiety inventory, and the hospital anxiety and depression scale. Mov Disord. 2011;26:407-15.

[243] Helvik AS, Engedal K, Skancke RH, Selbaek G. A psychometric evaluation of the Hospital Anxiety and Depression Scale for the medically hospitalized elderly. Nord J Psychiatry. 2011;65:338-44.

[244] Loosman WL, Siegert CE, Korzec A, Honig A. Validity of the Hospital Anxiety and Depression Scale and the Beck Depression Inventory for use in end-stage renal disease patients. Br J Clin Psychol. 2010;49:507-16.

[245] Tiringer I, Simon A, Herrfurth D, Suri I, Szalai K, Veress A. Occurrence of anxiety and depression disorders after acute cardiac events during hospital rehabilitation. Application of the Hospital Anxiety and Depression Scale as a screening instrument. Psychiatr Hung. 2008;23:430-43.

[246] Whelan-Goodinson R, Ponsford J, Schonberger M. Validity of the Hospital Anxiety and Depression Scale to assess depression and anxiety following traumatic brain injury as compared with the Structured Clinical Interview for DSMIV. J Affect Disord. 2009;114:94-102.

[247] Fatt QK, Atiya AS, Heng NC, Beng CC. Validation of the hospital anxiety and depression scale and the psychological disorder among premature ejaculation subjects. Int J Impot Res. 2007;19:321-5.

[248] Mondolo F, Jahanshahi M, Grana A, Biasutti E, Cacciatori E, Di Benedetto P. The validity of the hospital anxiety and depression scale and the geriatric depression scale in Parkinson's disease. Behav Neurol. 2006;17:109-15.

[249] McCue P, Martin C, Buchanan T, Rodgers J, Scholey A. An investigation into the psychometric properties of the Hospital Anxiety and Depression Scale in individuals with chronic fatigue syndrome. Psychol Health Med. 2003;8:425-39.

[250] Roberts SB, Bonnici DM, Mackinnon AJ, Worcester MC. Psychometric evaluation of the Hospital Anxiety and Depression Scale (HADS) among female cardiac patients. Br J Health Psychol. 2001;6:373-83.

[251] Marinus J, Leentjens AF, Visser M, Stiggelbout AM, van Hilten JJ. Evaluation of the hospital anxiety and depression scale in patients with Parkinson's disease. Clinical neuropharmacology. 2002;25:318-24.

[252] Juang KD, Wang SJ, Lin CH, Fuh JL. Use of the hospital anxiety and depression scale as a screening tool for patients with headache. Zhonghua Yi Xue Za Zhi (Taipei). 1999;62:749-55.

[253] Stafford L, Berk M, Jackson HJ. Validity of the Hospital Anxiety and Depression Scale and Patient Health Questionnaire-9 to screen for depression in patients with coronary artery disease. Gen Hosp Psychiatry. 2007;29: 417-24.

[254] Flint AJ, Rifat SL. Factor structure of the hospital anxiety and depression scale in older patients with major depression. Int J Geriatr Psychiatry. 2002;17:117-23.

[255] Golden J, Conroy RM, O’ Dwyer AM. Reliability and validity of the Hospital Anxiety and Depression Scale and the Beck Depression Inventory (Full and FastScreen scales) in detecting depression in persons with hepatitis C. J Affect Disord. 2007;100:265-9.

[256] Poole NA, Morgan JF. Validity and reliability of the Hospital Anxiety and Depression Scale in a hypertrophic cardiomyopathy clinic: The HADS in a cardiomyopathy population. Gen Hosp Psychiatry. 2006;28:55-8.

[257] Mitchell AJ, Meader N, Symonds P. Diagnostic validity of the Hospital Anxiety and Depression Scale (HADS) in cancer and palliative settings: A meta-analysis. J Affect Disord. 2010;126:335-48.

[258] Lloyd-Williams M, Friedman T, Rudd N. An analysis of the validity of the Hospital Anxiety and Depression scale as a screening tool in patients with advanced metastatic cancer. J Pain Symptom Manage. 2001;22:990-6.

[259] Karimova G, Martin C. A psychometric evaluation of the Hospital Anxiety and Depression Scale during pregnancy. Psychol Health Med. 2003;8:89-103. 